Espacio, Tiempo y Forma, Serie VII, $H .^{a}$ del Arte, $t .16,2003$, págs. \$1-110

\title{
La popularización de la arquitectura
}

\author{
Esther Alegre Carvajal \\ Profesora Historia del Arte. UNED
}

\begin{abstract}
RESUMEN
ABSTRACT

La popularización de la arquitectura es el The 'popularizacion' of the architecture is proceso en el que elementos o conjuntos

arquitectónicos aáquieren un carácter popular que originariamente no tenian; es la manera de recepción, de apropiación y de asimilación que llevan a cabo los constructores populares de modelos, técnicas y valores de la arquitectura culta $y$, en última instancia, la forma de interacción entre la arquitectura popular y la arquitectura de las élites. the process in which elements or architectonic sets acquire a vernacular character that originally they did not have; it is the way of reception, appropriation and assimilation that carry out the vernacular constructors of models, techniques and values of the cultured architecture and, in last instance, the form of interaction between the vernacular architecture and the architecture of the elites.
\end{abstract}

En las últimas décadas muchos aspectos de la actividad humana, que en el pasado no se contemplaban como materia de estudio, o se consideraban triviales, han sido reclamados como propios por parte de los historiadores. Entre ellos se encuentra la investigación sobre la cultura popular que ha pasado a ser un tema de máximo interés ${ }^{1}$.

1 Partiendo de los clásicos estudios de BAJTIN, Mijail: Cultura popular en la Edad Media y el Renacimiento. Madrid, 1987; y BuRKE, Peter; La cultura popular en la Europa moderna, Madrid, Alianza Editorial, 1991 (en la pág. 17, hace referencia a la abundancia de estudios que se han realizado hasta la edición española de su propio trabajo, sobre diferentes aspectos de la cultura popular) se ha abierto una línea de investigación muy fructífera que atiende al estudio de la cultura popular en su relación con la cultura de las élites y que se ha concretado en trabajos como: CHARTIER, Roger: Culture populaire: retour sur un concept historigraphique, Valencia, 1994; CHARTIER, Roger: Espacio público, crítica y desacralización 
En arquitectura, la comprensión de lo popular abarca un ámbito del conocimiento tan sugestivo como amplio y difuso, que está todavía por especificar: ¿Qué es lo popular? ¿Dónde empieza y termina lo popular? ¿Qué significa la popularización?. Desde luego no son conceptos fácilmente definibles, ni evaluables, ni teorizables, desde los tradicionales puntos de vista de la historia del arte ni de la historia de la arquitectura ${ }^{2}$.

Popular, señala el diccionario de la Real Academia referido a una cultura, es «aquélla que el pueblo considera propia y constitutiva de su tradición». Aplicada esta definición a la arquitectura, popular sería aquélla que una sociedad reconoce como suya y que arraiga en su propia tradición, sin necesidad de que haya sido por ella misma producida sino simplemente que la haya recibido como propia. Esta breve alusión a lo popular nos da la pauta para adentrarnos en el tema que queremos exponer: la popularización de la arquitectura ${ }^{3}$, cuyo objeto no va a ser otra cosa que una disquisición sobre esa arquitectura que una sociedad recibe y reconoce como suya y que arraiga y se mantiene en sus más íntimas costumbres.

Necesariamente, antes de seguir adelante, debo precisar que no estoy hablando, estrictamente, de arquitectura popular, sino, como ya he indicado, de popularización, es decir, del proceso en el que elementos o conjuntos arquitectónicos adquieren un carácter popular que originariamente no tenían; de la recepción, la apropiación y la asimilación que llevan a cabo los constructores populares de modelos, técnicas y valores de la arquitectura culta y, en última instancia, del proceso de interacción entre la arquitectura popular y la arquitectura de las élites. Aunque bien es cierto que estos elementos o conjuntos arquitectónicos ya popularizados forman parte del elenco de la arquitectura popular y que con ella comparten todos y cada uno de sus problemas, a los que obligatoriamente tendré que referirme.

El arte popular es un tema genérico, ambiguo e impreciso, cuya acotación y definición comporta múltiples dificultades que han dado lugar a suposiciones

en el siglo XVII, Barcelona, 1995; CHRISTiAn, William A.: Religiosidad local en la España de Felipe II, Madrid, 1991; García FeRnánDEZ, Ernesto: Cultura de élites y cultura popular en Occidente, Bilbao, 2001; MUIR, Eduard: Fiesta y rito en la Europa Moderna, Madrid, 2001; entre otros muchos estudios.

${ }^{2}$ La mencionada proliferación de estudios sobre cultura popular no ha incluido el ámbito de la historia de la arquitectura como objeto de estudio, y escasamente el de la historia del arte. De tal forma que, aunque los estudios sobre cultura popular encuentren un espacio propio en la investigación estrictamente histórica, en la historia de la arquitectura su alcance no se ha concretado.

${ }^{3}$ BURKE, Peter: Formas de Historia Cultural, Madrid, Alianza Editorial, 1997, págs. 165-168. Analiza el fenómeno de Popularización del Renacimiento, y lo explica utilizando el concepto «popularización» en el mismo sentido que lo vamos a exponer aquí. Habla de la interacción, de la apropiación, de la recepción y de la asimilación de la cultura erudita del renacimiento por parte de las clases populares. Aunque hay que precisar que no hace ninguna referencia a la popularización de la arquitectura renacentista, hecho que vamos a explicar unas páginas más adelante. 
muy diversas y a veces han desatado importantes polémicas entre los especialistas. Los primeros estudios sobre la cultura popular se inician a finales del siglo XVIII y principios del siglo XIX, y son una de las múltiples consecuencias del movimiento romántico y de la aparición de los nacionalismos. Este primer acercamiento a «lo popular» tuvo como propósito la recopilación y el estudio de las canciones y los cuentos populares, lo que luego se ha conocido como «literatura popular»; estudio que no estuvo exento de polémica y desató un encendido debate entre los especialistas, donde un nutrido grupo de críticos pensaba que había que desecharla como categoría científica frente a otro grupo que la consideraba una categoría fundamental, debate que hoy está totalmente superado. En el ámbito de las artes plásticas los acercamientos a este tema han sido más sosegados, pero es posible que hayan carecido de la intención de buscar una hipótesis de trabajo generalizable, y que se hayan quedado sujetos exclusivamente al registro, más o menos especulativo, de algunas de sus manifestaciones ${ }^{4}$.

En el terreno de la arquitectura no es hasta casi la mitad del siglo $x x$, cuando se producen los primeros acercamientos a «lo popular», acercamiento que no parte de planteamientos etnográficos, antropológicos o históricos, sino que entiende la arquitectura popular como un hecho en sí mismo, apreciándola desde el punto de vista de su valor arquitectónico. Esta peculiar aproximación tiene su origen en la recuperación que, desde mediados del siglo xvill, se realizó de los diferentes estilos históricos en busca de un prototipo que pudiera sustituir a la antigüedad clásica como modelo universal. Así surgieron los historicismos, que a lo largo del siglo XIX originaron en primera instancia una revisión de lo medieval y posteriormente de otros estilos históricos, con una valoración y un estudio como un medio de oposición a lo clásico y en busca de una forma que representara la esencia nacional y el espíritu del pueblo, elementos que van a formar parte de la recuperación de lo popular. Este hecho se desarrolla dentro de un proceso general en el que el Arte se interpreta como un fundamento más de la historia general y, por tanto, como un ingrediente que ayuda a establecer la identidad colectiva, la identidad de la nación. Posteriormente, ya en los albores del siglo xx, se produce un acercamiento a «lo primitivo». El primitivismo se percibe o se asocia con vidas y sociedades más sencillas, con pensamientos y expresiones más puras, lo que lleva a la exaltación de la cultura campesina y popular, como una forma de ex-

4 Como venimos apuntando - ver notas 1 y 2- en el ámbito específico de los estudios históricos, sí se ha planteado el análisis de la cultura popular como una hipótesis de trabajo generalizable y por tanto sus estudios se integran plenamente en el discurso histórico e incluso tíenen eco significativo en programas docentes de universidades españolas, algo todavía impensable en el ámbito de estudio de la Historia de la Arquitectura. 
presión artística genuina y directa, y como testimonio de un tipo de creatividad innata ${ }^{5}$.

Todas estas ideas y percepciones son el sedimento ideológico que va a permitir que, tras el agotamiento del Movimiento Moderno, se produzca una recuperación real de la arquitectura ya denominada popular, hecho que comprende, por una parte, entenderla como una forma idónea para contrarrestar el modelo racionalista que se presentaba desvinculado de toda raíz histórica; y por otra, considerarla una solución básica que, dada su riqueza plástica, supliría la incapacidad compositiva que había dejado como herencia ese movimiento moderno y que dio paso a las arquitecturas regionalistas. Igualmente, se pretendió someter a las arquitecturas populares a su estudio y su posterior reducción a un marco teórico que permitiera encontrar los principios de un habitat universal ${ }^{6}$.

Pero todo este proceso de recuperación de lo popular, mucho más complejo en su desarrollo que lo expuesto, se hizo desde esa concepción que se había conformado de lo primitivo, es decir, desde la exaltación de lo popular como algo sencillo y puro, pero con una valoración de lo «opuesto», como una categoría de lo "otro", frente a la cultura y a las experiencias que son más propias.

Esta percepción ha tenido importantes consecuencias ya que ha determinado una clara y contundente separación, en la apreciación, en la conceptualización y en los estudios, entre dos formas de arquitectura, entre dos categorías, la denominada arquitectura culta, histórica o estilística, "la propia», y su contrario la arquitectura popu$\operatorname{lar}^{7}$. Esta clásificación ha tomado carta de naturaleza y ha sido ampliamente aceptada $\mathrm{y}$ respetada a lo largo de todo el siglo $\mathrm{xx}$, $\mathrm{y}$ hasta hoy se sigue manteniendo ${ }^{8}$.

${ }^{5}$ La oposición a la cultura clásica y la necesidad de dotar de raíces históricas a los recientes nacionalismos, así como la valoración de lo primitivo, son elementos que están en el origen del movimiento de descubrimiento y gusto por lo popular, BURKE, Peter: La cultura popular..., págs. 45-47.

6 FISAC, Miguel: La arquitectura popular española y su valor ante la arquitectura del futuro, Madrid, 1952 y FERNÁNDEZ ALBA, Antonio: «Los documentos arquitectónicos populares como monumentos históricos, o el intento de recuperación de la memoria de los márgenes», en Arquitectura popular en España, Madrid, CSIC, 1990, págs. 21-32.

7 En este sentido es reveladora la idea expuesta por MANRIQUE, Jorge Alberto: «Categorías, modos y dudas acerca del arte popular», en La Dicotomía entre Arte Culto y Arte Popular, Coloquio Internacional de Zacatecas. Universidad Autónoma de México, 1979. págs. 256-257, donde afirma (...) lo que llamamos arte popular no tiene verdadera existencia sino en oposición al concepto de arte culto (...) Es decir, el concepto de arte popular nace para distinguir, no para definir (...). Teniendo en cuenta este hecho podemos entender todas las dificultades que existen para definir lo que es el arte popular, ya que en origen el concepto surge para aglutinar aquello que se intuye o se aprecia como no culto.

${ }^{8}$ Esta división no es exclusiva de la arquitectura, sino de toda la cultura. Actualmente, como venimos exponiendo, se han adoptado con éxito los términos cultura de élites y cultura popular, denominaciones que se van precisando cada vez más gracias a los trabajos destinados a estudiar la relación entre las dos categorías. Hecho que, reiteramos, no ocurre en los estudios de historia de la arquitectura. Incluso, más recientemente, esta visión dividida de la cultura en bloques ha llevado a algunos historiadores a determinar otro modelo binario, otras dos categorias: centro y periferia, idea que ha tenido un mayor calado en 
Así, académicamente, se entiende que existe una arquitectura técnica, erudita, culta y filosófica, origen de los estilos o arquitecturas históricas, que universaliza soluciones a través de reglas y cánones estéticos y que está compuesta por un conjunto de obras claves que deben ser el objeto, si no único al menos prioritario, de la historia de la arquitectura. Frente a ella y tajantemente separada, la arquitectura popular se entiende como un hecho constructivo local y artesanal que, profundamente enraizada en el medio ambiente y ligada al clima, a los materiales y a las funcionalidades sociales y económicas, no es otra cosa que una repetición de invariantes y de soluciones contrastadas y probadas durante generaciones.

Este acercamiento a lo popular, radicalmente separado de lo culto y en última instancia del concepto general de arquitectura, ha tenido efectos tan positivos como las grandes recopilaciones de arquitectura popular realizadas por estudiosos como Carlos Flores, Luis Feduchi o Tomás Nieto Taberné ${ }^{9}$ que libraron a estas construcciones de simplistas percepciones folkloristas, de su valoración a través de criterios de pintoresquismo, de nostalgia o de simpatía, así como, de prejuicios locales, regionales o nacionalistas, para presentarlas por su propio valor como hecho construido, es decir, por su significado arquitectónico.

Sin embargo, en mi opinión, en los últimos años se ha producido el anquilosamiento de esta visión; el supuesto creciente interés y desarrollo de los estudios sobre arquitectura popular, no ha hecho más que ahondar en esta separación, cada vez más extreria, en la conceptualización de la arquitectura en dos categorías opuestas, entre lo que se entiende por arquitectura culta y arquitectura popular y en su radical diferencia, lo que ha provocado el desarrollo de una visión de «lo popular» en arquitectura como un hecho único, es decir, con una única vertiente, marginal y simple, en la que sólo se han registrado las diferencias regionales de las distintas manifestaciones, reduciendo el problema del estudio de la arquitectura popular a un simple camino: el de catalogar ${ }^{10}$, actuación que se ha convertido en una

los estudios de Historia del Arte. BURKE, Peter: El Renacimiento Europeo. Centro y periferia. Barcelona, Crítica, 2000.

${ }^{9}$ Flores, Carlos: La arquitectura popular española, Madrid, Editorial Aguilar, 5vv, 1973; FLoRes, CarIos: La España popular, Madrid, Editorial Aguilar, 1979; FLoREs, Carlos: Pueblos y lugares de España. Madrid, Editorial Espasa-Calpe, 1991; FEDUCH, Luis: Itinerarios de arquitectura popular española. Varios volúmenes. Barcelona, Editorial Blume, 1974; Nieto Taberné, Tomás y Alegre CARVAJAL, Esther: El Románico en Guadalajara, Madrid, Estudio Museo, 1991; Nieto TabernÉ, Tomás y Alegre Carvajal, Esther: El Románico en Cuenca, Cuenca, Estudio Museo, 1994; Nieto Taberné, Tomás y Alegre CarvajaL, Esther: Los jardines de Pastrana. Guadalajara, AACHE Ediciones, 1997; NIETo TABERNÉ, Tomás, Alegre CARVAJAL, Esther: Guia de la Arquitectura Negra de Guadalajara, Guadalajara, 1998.

10 En el ejercicio de catalogar se ha seguido sistemáticamente el modelo del análisis tipológico, apoyado en una idea que ha vertebrado hasta la fecha todo el conocimiento que se tiene sobre arquitectura popular: la pervivencia casi inmutable de los modelos a lo largo del tiempo. No voy a cuestionar la indudable realidad de la repetición de prototipos, ni la necesidad básica de realizar análisis tipológicos en arquitectura popular, pero sí el que este modelo, al establecerse como único, ha dejado de lado los 
cuestión apremiante por la vertiginosa desaparición por sustitución que están sufriendo estas construcciones.

Por otra parte, sin que el objetivo catalogador se haya cumplido, el asunto ha sufrido una simplificación que ha mantenido el problema de lo popular en arquitectura en un lugar marginal, no solo como concepto intelectual, pese a los muchos entusiasmos que pueda parecer que despierta, sino, y sobre todo, como faceta de la arquitectura y desde luego como una materia a incorporar a la historia de la misma, cuestión ésta que ni siquiera se contempla ${ }^{11}$. La crítica y la metodología necesaria para estudiarla no se ha desarrollado adecuadamente, carecemos de instrumentos de análisis y crítica, que se puedan comparar a los que poseemos para investigar, sistematizar e interpretar al arte culto, para acercarnos a sus manifestaciones. Parece que la arquitectura popular no admite otra perspectiva que la de enunciarla y describirla.

El problema, desde mi punto de vista, se encuentra en un callejón sin salida. Los estudios sobre arquitectura popular, como ya he dicho, se han estancado en su mera faceta catalogadora, destinada más a convertir esta arquitectura en un producto turístico de consumo que en un elemento cultural necesitado de trabajos científicos integradores ${ }^{12}$. Al tiempo, se puede afirmar el fracaso de esta labor ca-

estudios evolutivos o históricos y no ha argumentado suficientemente la idea de pervivencia al no pretender establecer un contexto evolutivo de las construcciones populares. El concepto de que la arquitectura popular tiene una Historia ha sido obviado, al menos implícitamente, por lo que podría denominarse el análisis clásico. Sin embargo, cuando las tipologías de construcciones populares se analizan en su contexto histórico y en su desarrollo evolutivo, revelan cómo algunos modelos no han sido el resultado de cubrir las necesidades primarias de una comunidad, ni han nacido ligadas al clima, a los materiales o a la tradición cultural de esa colectividad, sino que son producto de la recepción, la asimilación y la apropiación de otras tradiciones culturales o de la interacción entre elementos cultos y elementos populares. Así lo pusimos de manifiesto en Nieto Taberné, Tomás y Alegre CarVajal, Esther: Los jardines de Pastrana... donde analizamos el proceso de implantación y desarrollo de los jardines populares pastraneros a partir del conocimiento y asimilación de los jardines moriscos importados por individuos de esta comunidad.

$"$ Historiadores como Kubler, George: "Las Artes, nobles y llanas" en La Dicotomía entre Arte Culto y Arte Popular. Coloquio Internacional de Zacatecas. Universidad Autónoma de México, 1979, pág. 27, en el año 1979 ya manifestaban esta carencia para el conjunto de la Historia del Arte «...el estudio del arte popular no puede hacerse sin el conocimiento pleno de las bellas artes. Ni debería nunca confiarse exclusivamente a los sociólogos, porque su estudio es tal vez la última tarea que le resta a la disciplina humanista de las artes visuales...».

${ }_{12}$ No es este el lugar adecuado para enumerar la multitud de publicaciones, de medios audiovisuales o de páginas en Internet que existen en las que se describe, siempre superficialmente, la arquitectura popular de un pueblo, una comarca, una provincia, una región, etc. como elemento de atracción turística. Tampoco para analizar la grave amenaza que supone para el patrimonio arquitectónico popular su comercialización, la gestión económica que se hace de él, aunque sí lo es para censurar un hecho: al constante riesgo de desaparición de la arquitectura popular, por ruina y abandono, se ha unido un peligro de igual envergadura, el tipo de intervención que se realiza para su conservación y comercialización. Esta intervención suele reducirse a la "sustitución» del edificio y al «fachadismo», es decir al mantenimiento en fachada de unos determinados elementos, como canecillos, balcones, rejas, dinteles de piedra, etc. 
talogadora que se centra, de forma reiterada, sobre conjuntos de edificios repetidamente clasificados, con escasas nuevas aportaciones, cuyo resultado es un cúmulo de trabajos que recogen los mismos elementos, analizados bajo los mismos criterios, todo ello debido a la carencia de una reflexión crítica y una aproximación teórica que profundice en el verdadero problema. Igualmente se puede afirmar el fracaso de toda esta labor como medio de salvaguardar el patrimonio construido popular que, en su conjunto, desaparece irremisiblemente.

Expuesto este panorama, es fácil comprender que el problema de lo popular en arquitectura no constituye un tema sencillo que se pueda articular desde la simplificación, sino desde su propia complejidad y desde la riqueza que se intuye cuando se advierte el enorme conjunto de obras que recoge esta categoria.

En primer lugar debemos precisar cómo, bajo la etiqueta de arquitectura popular, se ha englobado un vasto grupo de edificaciones de aspecto popular: desde construcciones auxiliares para el ganado como tinadas, parideras o tainas, edificios de vivienda como casonas solariegas o viviendas mínimas, pasando por inmuebles públicos, religiosos, industriales o representativos, como hornos, fraguas, molinos, lavaderos, iglesias, conventos, monasterios, ermitas, ayuntamientos, pósitos, etc., hasta componentes de la ciudad como los soportales. Ejemplos que, tal vez, sólo tienen en común su escasa o nula monumentalidad, su aparente resistencia a encuadrarse dentro de los estilos artísticos oficialmente reconocidos y su difícil cotejo documental, más que cualquiera de las características de funcionalidad, ligazón al clima, al entorno y a los materiales, o por un proceso constructor determinado, exclusivamente, por la transmisión de técnicas preindustriales y oficios entre generaciones de modo automático, consideraciones utilizadas para definir la arquitectura popular.

En un análisis sosegado es imposible mantener este ingente conjunto de arquitecturas dentro de unos mismos límites, de definición y características.

De hecho, son abundantes las paradojas, contradicciones e incluso errores que, por mantener estos límites, se puecien encontrar en los estudios de arquitectura popular. Así, por ejemplo, una de las grandes confusiones con respecto a la arquitectura popular, es la categoría de "rural», utilizada para agrupar a un gran número de edificios ubicados en el actual espacio rural, que no se corresponde con el espacio rural de épocas anteriores, construcciones que de forma evidente per-

\footnotetext{
descontextualizados, que crean una ambientación que puede ser grata para la actividad turística, pero que no se preocupa de la conservación de la estructura del edificio, de su tipología, de su construcción y mucho menos de su singularidad, y por tanto elimina los elementos necesarios para el conocimiento, el estudio y la interpretación de esa arquitectura.
} 


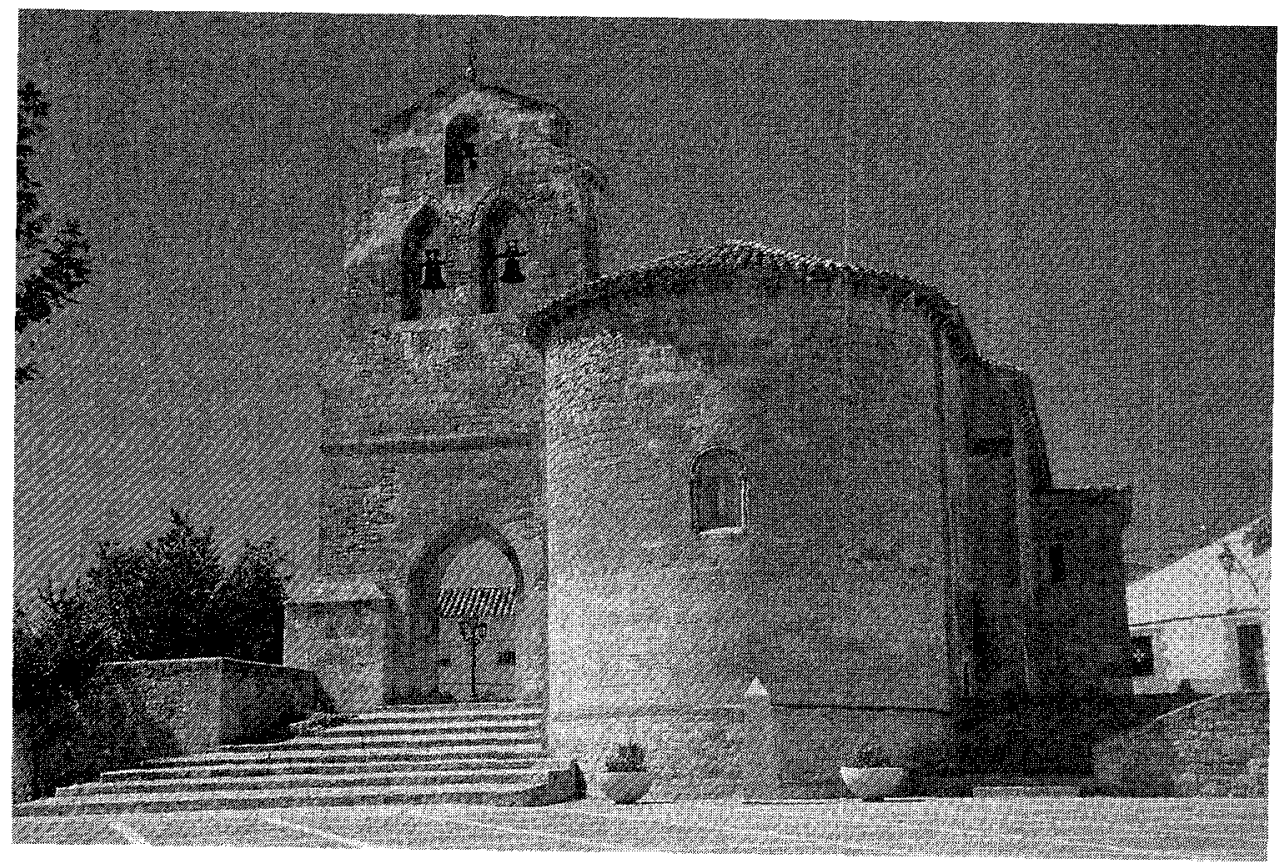

Fig. 1. Iglesia románica de Arcas (Cuenca).

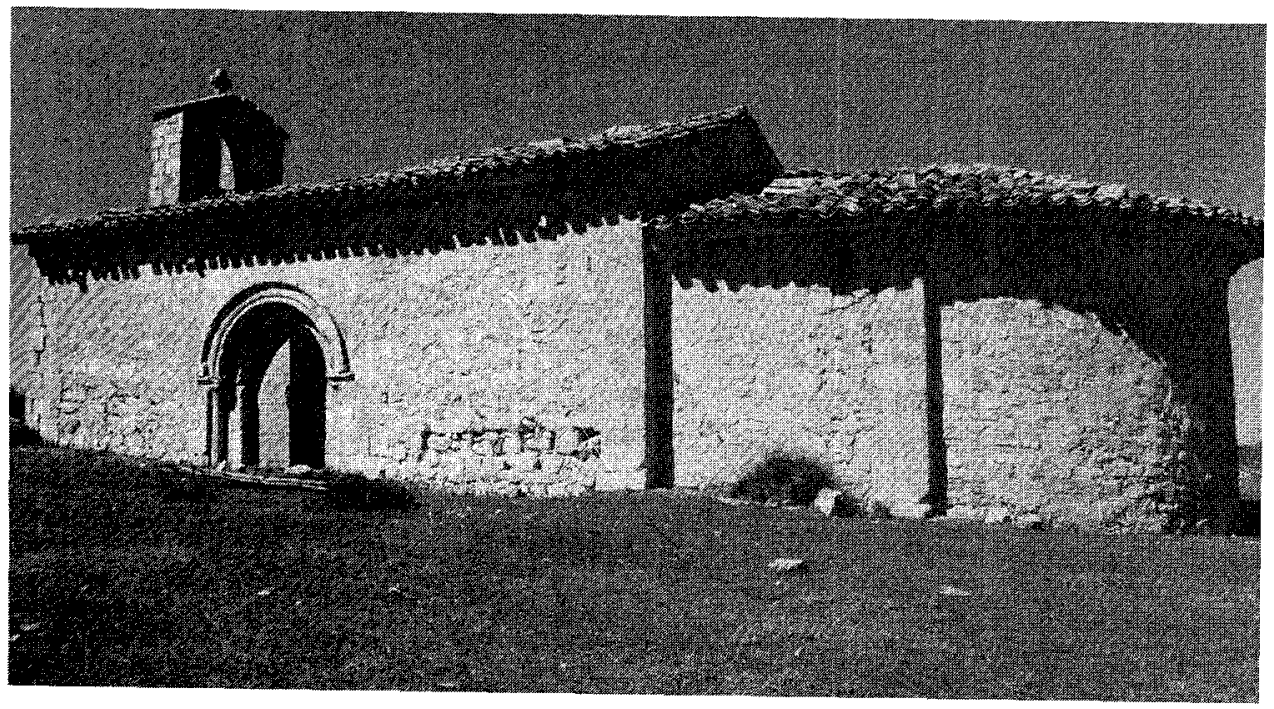

Fig. 2. Iglesia románica de Villar del Gato (Guadalajara). 


\section{La popularización de la arquitectura}

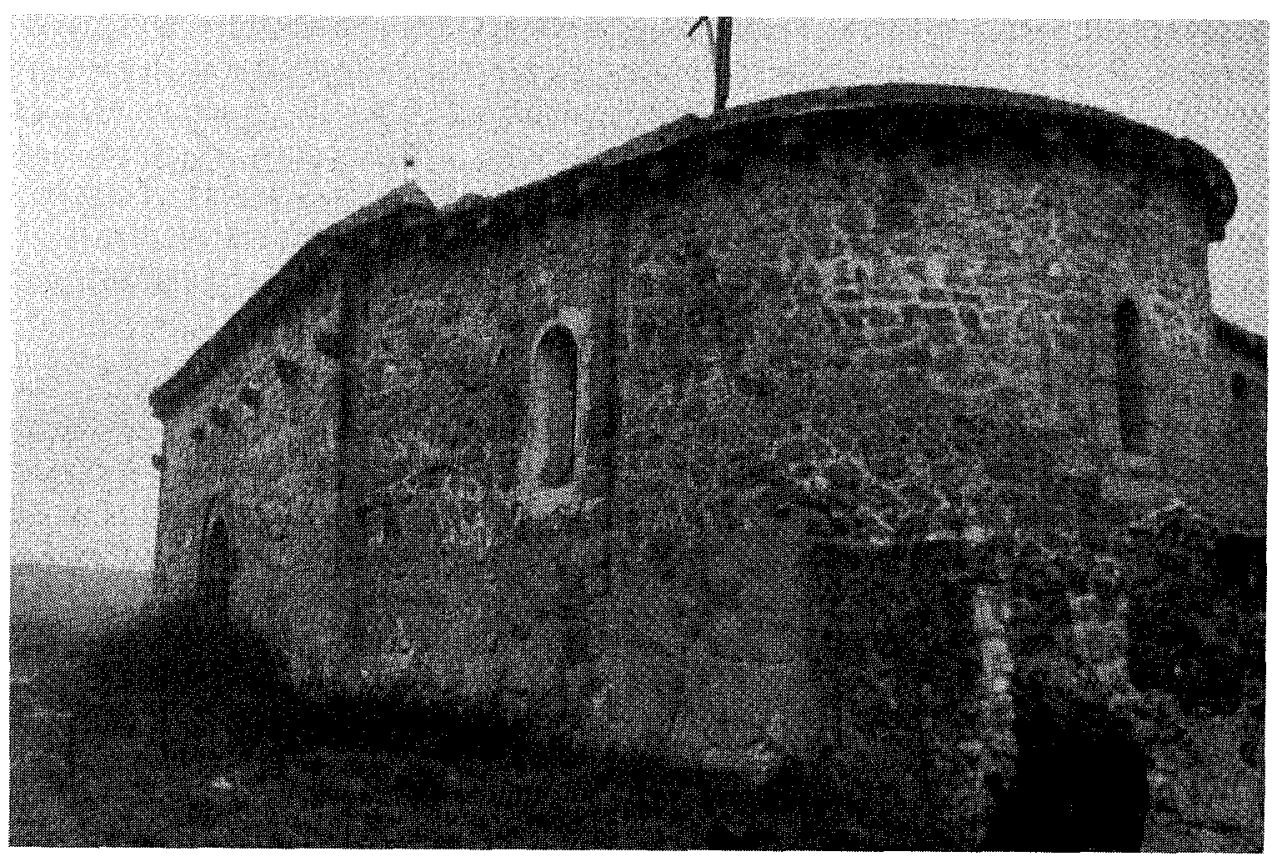

Fig. 3. Iglesia románica de Hortizuela (Cuenca).

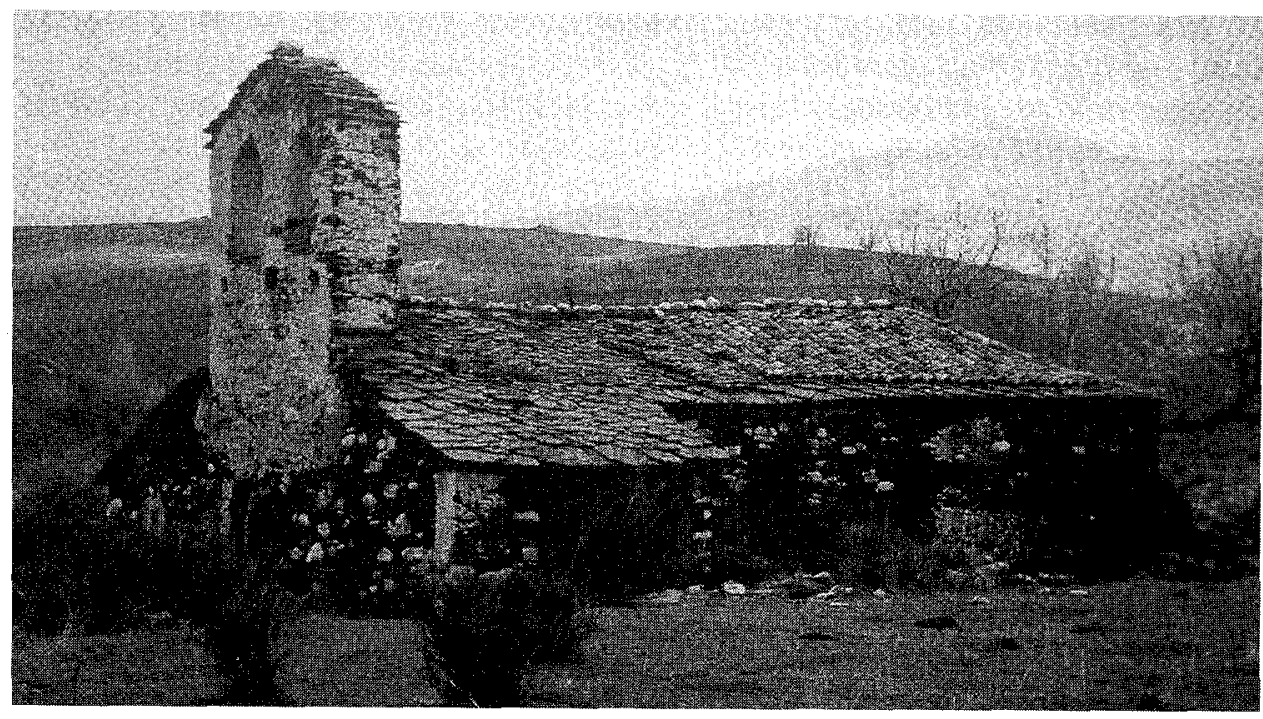

Fig. 4. Iglesia románica de Matallana (Guadalajara). 
tenecen a un estilo artístico, aunque éste aparezca con un aspecto más o menos popular. Paradigmático en este sentido es el caso del adjetivado románico rural, etiqueta con la que se quiere solventar el problema de que a un grupo de iglesias erigidas en este estilo, unas veces se las entienda y se las estudie dentro de la arquitectura culta y de su propio estilo artístico y se incorporen, sin timidez, a la historia de la arquitectura, y otras se expliquen como una muestra excelente de arquitectura popular con referencias puntuales al románico, un lenguaje artístico culto e internacional.

Este mismo ejemplo pone de relieve otro de los grandes contrasentidos que presentan los estudios sobre arquitectura popular: es indudable que desde un punto de vista formal, algunas construcciones populares presentan en su ejecución la carencia de una tradición arquitectónica que las sustente, mientras que otras se distinguen por una factura que las distancia, por el alto refinamiento en su acabado, de la arquitectura propiamente popular aunque sus formas no se puedan asimilar a lo que frecuentemente llamamos arte culto u oficial.

El problema que plantean todas estas paradojas es el mismo: existe un enorme conjunto de construcciones tildadas y aceptadas como populares, que en un análisis más profundo se distancian de esta adjetivación sin que sobre ellas se dé una explicación satisfactoria. Arquitectura popular no es todo lo que se denomina como tal, ni es todo lo que actualmente muestra una imagen popular.

Por tanto, hay otra realidad, otro principio, dentro del problema de «lo popular» en arquitectura; es decir, tal y como lo expresamos al principio de estas páginas, existe un proceso en el que elementos o conjuntos arquitectónicos adquieren un carácter o un aspecto popular que originariamente no tenían, un proceso de popularización de la arquitectura.

Con ello nos situamos en la otra vertiente del problema, en la «enfáticamente» denominada arquitectura culta, origen de los estilos o arquitecturas históricas que universaliza soluciones a través de normas y modelos estéticos. $Y$ entramos de lleno en la cuestión, ya que el proceso de popularización se despliega a partir de esas producciones.

Cuando la arquitectura culta crea una serie de soluciones arquitectónicas como tipologías, formas constructivas, espacios, escalas, juegos de luz, de distribución, de ordenación, conjuntos urbanos, etc. y las sintetiza en un estilo artístico concreto, estos principios una vez contrastados y probada su funcionalidad, pueden cristalizar en modelos que se integren dentro del ámbito de lo popular. Este es un cambio que se formaliza: primero, mediante una reducción de la complejidad técnica del original, hasta adquirir como lenguaje una apariencia popular (imágenes $1,2,3, y$ ) ; segundo, a través de una simplificación de las tipologías definidas 
(imágenes 5 y 6, 0 17, 18, 19 y 20); y tercero, con una disminución a la máxima de los componentes del estilo artístico (imágenes 7 y 8 o 9, 1011 y 12); con ello se llega a la elaboración de modelos fáciles de repetir que, valorados fundamentalmente en su utilitarismo, quedan ligados a las condiciones ambientales en las que surgen, a los medios y modos de vida donde se implantan, así como a la idiosincrasia, a las maneras de relación y a las actividades sociales y económicas de sus constructores y de la sociedad que las asume. Se produce una fusión con ella, prácticamente, total; de tal manera que parece que es este medio, esta sociedad, la que originó estos tipos, que se tornan ya para siempre en invariantes arquitectónicos y culturales constitutivos de su tradición ${ }^{13}$.

Es decir, el procedimiento que manifiesta la arquitectura, según el cual partiendo de diseños clásicos originales, establecidos por los grandes estilos artísticos y mediante un sistema de esquematización y de disminución de la complejidad constructiva y simbólica, se llega a lenguajes y a expresiones netamente populares, es lo que entendemos por «popularización» (imágenes 13, 14, 15 y 16).

En este sentido, podemos afirmar que hay una parte de la arquitectura culta que es propiamente popular, o que, al menos, existe un ámbito amplio y difuso en el que ambas manifestaciones se confunden, se desdibujan y se reúnen en un único resultado. La línea de separación entre lo culto y lo popular, entre lo creado por el artista y lo trasmitido repetitivamente por la tradición, se olvida, ambas creaciones se fusionan y el resultado es una nueva realidad arquitectónica, la popularizada.

Este ámbito de unión, de influencia, de interacción ${ }^{14}$, ha sido, a mi juicio, un hecho permanente a lo largo de toda la historia de la arquitectura, hasta que la industrialización integral del siglo xx supuso el aniquilamiento de las formas de vida tradicionales, la pérdida definitiva de los oficios populares y con ellos el irremediable final de la arquitectura popular, tanto como corriente constructiva que se venía desarrollando desde los mismos orígenes de la arquitectura, como de las realizaciones logradas por ella que, tras el abandono de estas formas de vida ancestrales, caen en el olvido, la decadencia y la sustitución.

${ }^{13}$ Chueca GolTIA, Fernando: Invariantes castizos de la arquitectura española. Madrid, Dossat, 1981. Con este trabajo Fernando Chueca introdujo el concepto de invariante en el estudio de la arquitectura española, definiéndolo como pág. 28 (...) un invariante es una cosa que, cuando otras cosas ligadas a ella se modifican, permanece sin sufrir cambio o alteración (...).

${ }_{14}$ BURKE, Peter: Formas de Historia..., insiste reiteradamente en la idea de la interacción, pág. 163 (...) sería más fructífero centrarse en la interacción de la cultura erudita y la cultura popular que intentar definir lo que las separa (...); pág. 176 (...) seguramente sería más fructífero si los historiadores culturales dejaran de lado la cultura popular en sí misma - como han estado haciendo-y centraran su atención en el estudio del largo proceso de interacción de los elementos cultos y los elementos populares $(\ldots)$. 


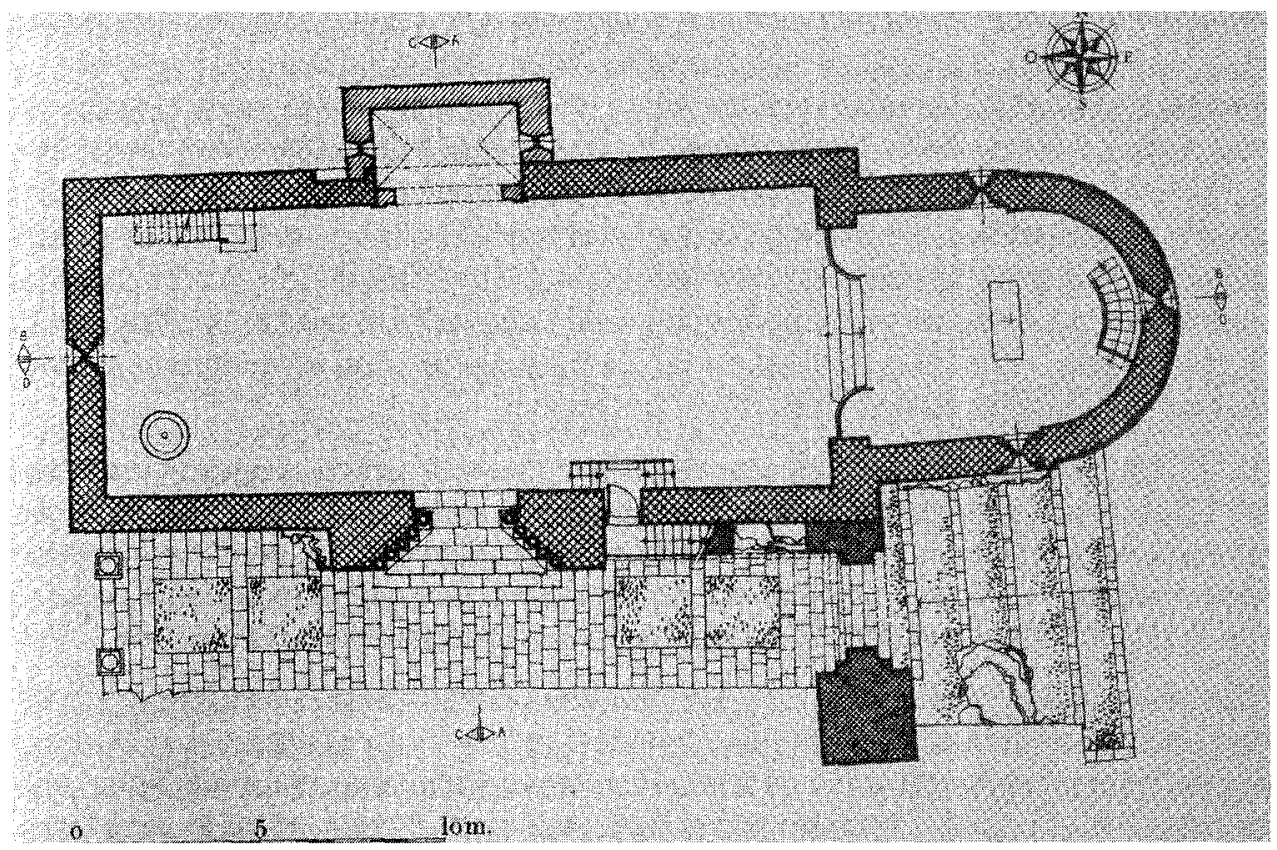

Fig. 5. Planta de la Iglesia románica de Arcas (Cuenca).

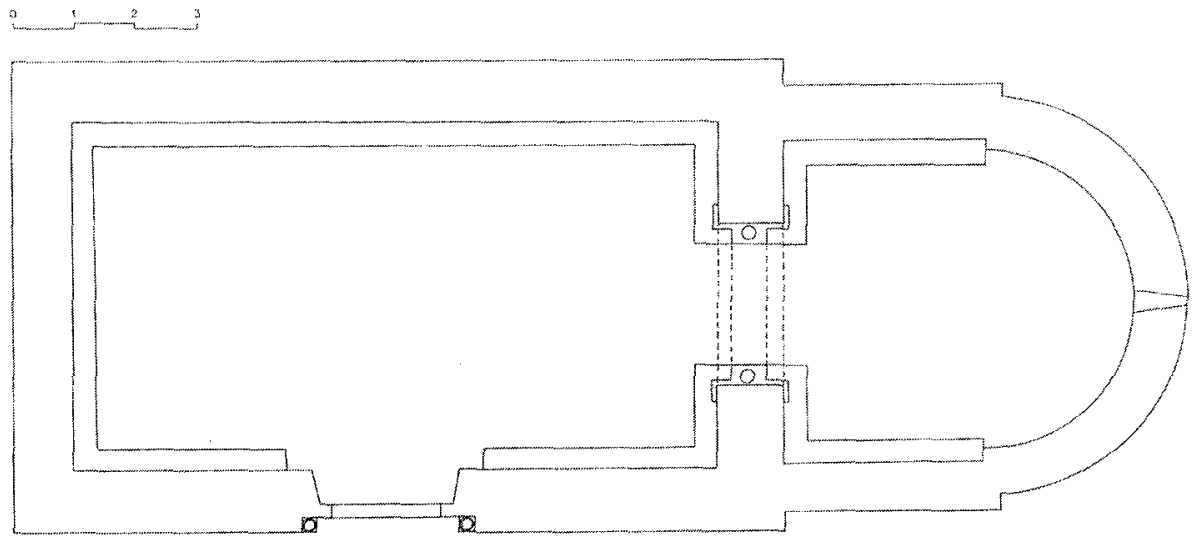

Fig. 6. Planta de la iglesia románica de Villar del Gato (Guadalajara). 
Este ámbito de integración se ha ido conformando al ritmo de los propios estilos artísticos, ya que son ellos los que elaboran modelos y tipologías arquitectónicas propias que, reducidas y esquematizadas, se convierten en su semblante popular. Por tanto, hablar de la popularización de la arquitectura es casi equivalente a hablar de las expresiones populares de los grandes estilos artísticos, aunque, como veremos más adelante, no es éste el único camino de la popularización.

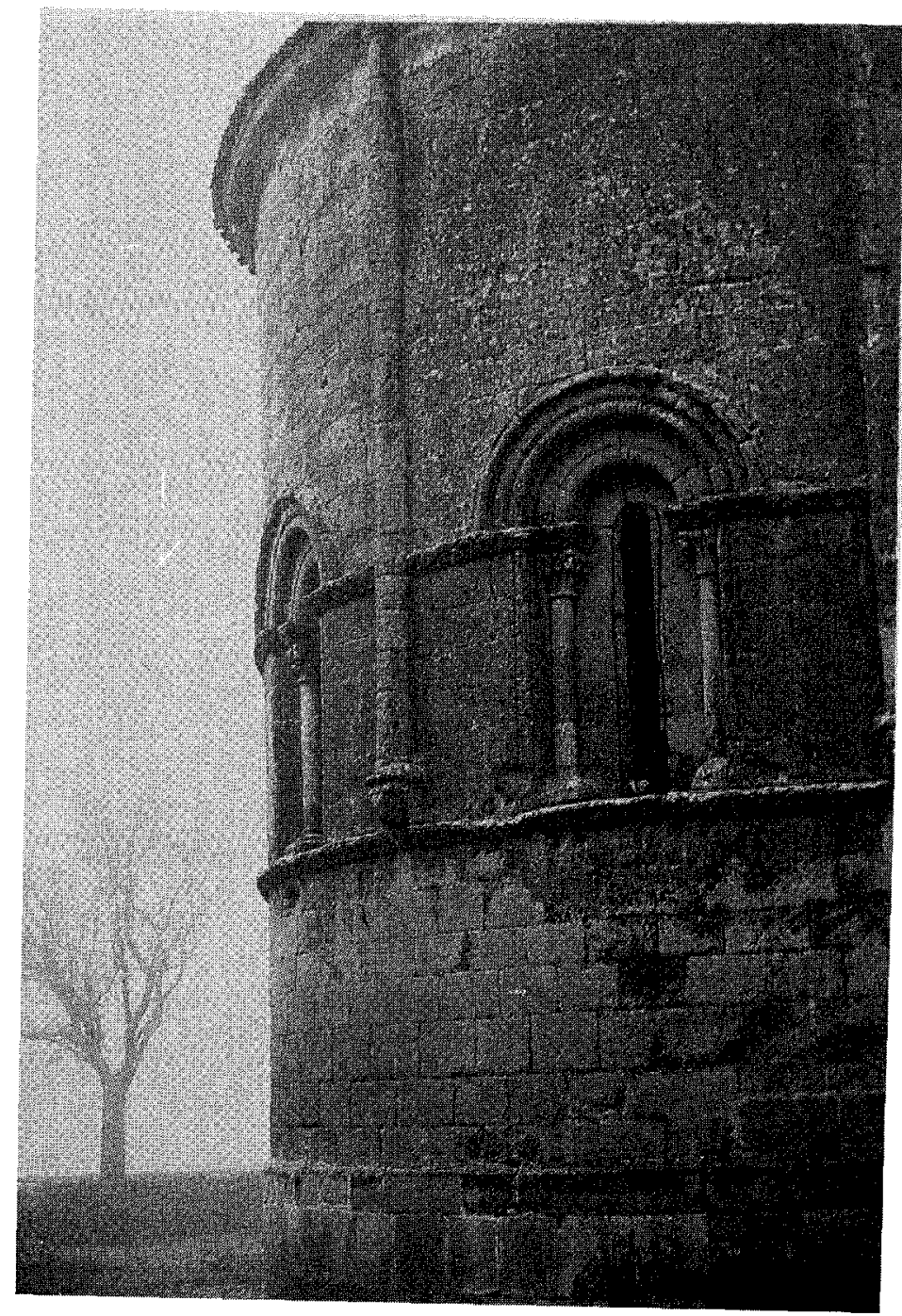

Fig. 7. Ábside de la iglesia de la Santísima Trinidad de Atienza (Guadalajara). 


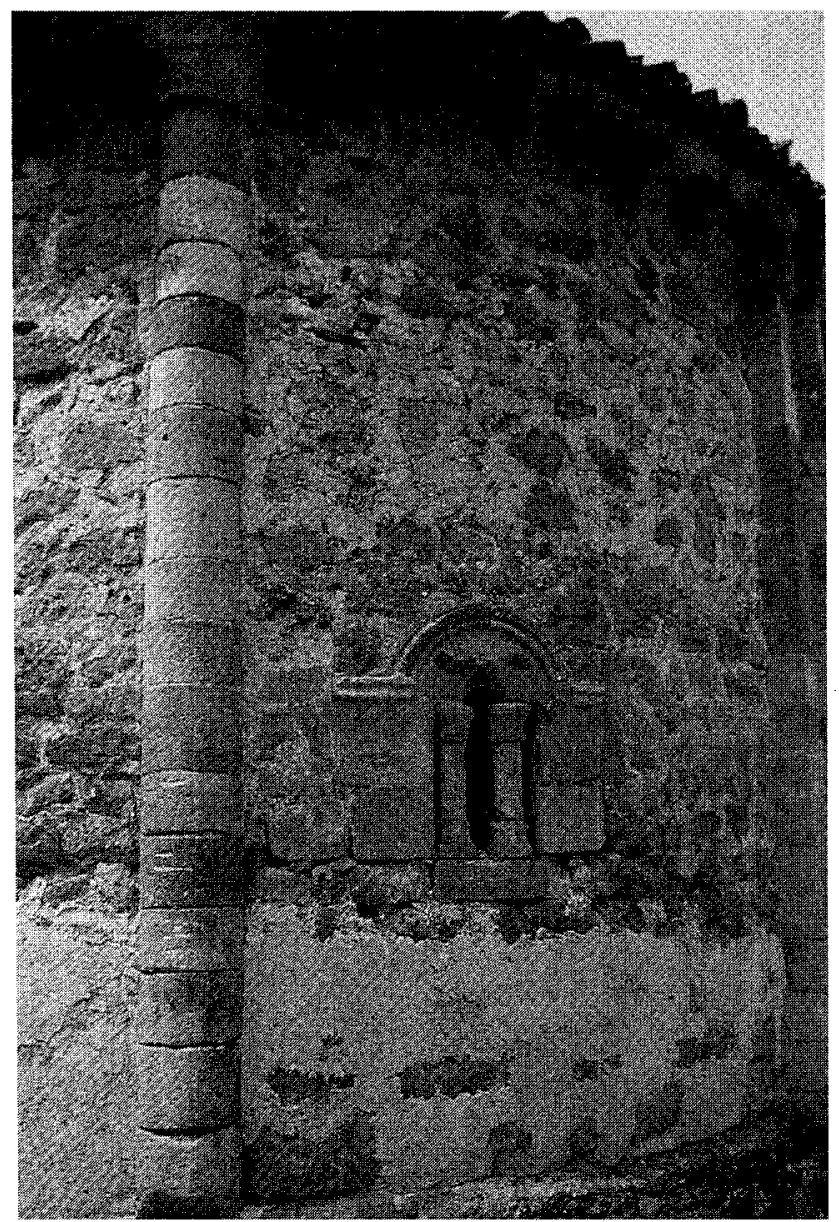

Fig. 8. Ábside de la iglesia de Cereceda (Guadalajara).

Cada estilo artístico comparte un lugar común con la arquitectura popular, tiene su propia imagen popular ${ }^{15}$. $Y$ es el conjunto de estas magníficas construcciones, el que ha sufrido más directamente la confusión y la deformación de los en-

${ }^{15}$ Estas ideas vertebran los trabajos: Nieto TabernÉ, Tomás y Alegre CaRvajal, Esther: El Románico en Guadalajara, Madrid, Estudio Museo, 1991; Nieto Taberné, Tomás y Alegre Carvajal, Esther: El Románico en Cuenca, Cuenca, Estudio Museo, 1994. En ellos se realiza el estudio y el catálogo de los edificios románicos de las provincias de Guadalajara y Cuenca, 285 en total, concediendo, tanto a las manifestaciones cultas como a las populares, el mismo tratamiento a la hora de ser catalogadas y dibujadas, hecho que permite un contraste riguroso de las distintas versiones de la arquitectura, y que revela fehacientemente la tesis expuesta de que cada estilo artístico tiene su propia expresión popular. 
foques históricos en torno a esta arquitectura; el que, como ella, ha sido reiteradamente olvidado, arrinconado y escasamente valorado, siendo excluidas sus manifestaciones de la historia de los estilos artísticos y por tanto de la historia de la arquitectura... convirtiéndose en un corpus de (...) objetos perdidos en la memoria de los márgenes $(. . .)^{16}$.

Sin embargo, la popularización de la arquitectura, la manifestación popular de los estilos artísticos, es un aspecto que atañe directamente a la propia historia de la arquitectura, ya que afecta a la visión estabilizada que se tiene de los estilos artísticos y de su evolución, al tiempo que altera, en cierta medida, la idea de seriación y superposición de unos sobre otros.

Lo cierto es que al estudiar las fases populares de la arquitectura y al entrever el proceso de popularización de los estilos sus límites tradicionales necesariamente se amplían y dilatan. Estilo es un concepto difuso que, utilizado con unos criterios de ordenación, sistematización y pedagógicos, permite acometer el análisis y el aprendizaje de la historia de la arquitectura; sin embargo, al limitarse a examinar una selección de obras de prestigio, claves, especialmente significativas dentro del desarrollo de la historia del arte, sólo permite seguir la secuencia evolutiva de ese estilo en sus fases externas: cómo surge, cómo se transforma hacia su etapa de clasicismo y cómo se va desvirtuando, momento en el que es sustituido por originales modelos arquitectónicos, que se convierten en ei nuevo objeto de estudio, abandonando el anterior.

Siguiendo esta línea de análisis, se entiende que con la aparición de modernas formas artísticas las anteriores desaparecen sin más. Pero esto no ocurre así. Existe una fase final en la que se produce una variación interna del propio estilo artístico; en ella las formas y los sistemas asumen modos y usos íntimos que les van a permitir sobrevivir en el tiempo, consecuencia de una actividad artística que se ha hecho introvertida, pero que funciona como lenguaje generalizado, al servicio de una clientela fundamentalmente preocupada por un utilitarismo primario. Es decir, en su fase final el estilo se populariza y con ello deja de ser una actividad elitista, para convertirse en una manera de expresión generalizada que va a plasmarse en un elevadísimo número de construcciones ${ }^{17}$.

En su fase final, el sistema de representación sufre un desarrollo evolutivo que le lleva desde la creación del artista a la tarea del artesano, desde la excepcionalidad hasta la generalidad.

16 Fernández Alba, Antonio: Op. cit. pág. 21.

17 Nieto Taberné, Tomás, Alegre Cafvajal, Esther: El Románico en Cuenca... En este trabajo exponemos la tesis de cómo el último románico europeo se desarrolla en el ámbito geográfico de esta provincia, y de cómo este estilo artístico adopta una clara expresión popular en estos últimos ejemplos. El románico internacional se transforma en arquitectura popular. 
Sólo por el vasto conjunto de edificaciones que se ven afectadas por este proceso, las manifestaciones populares de un estilo son decisivas para su comprensión. Pero también, a través de ellas se advierte la repercusión real del mismo, la adaptabilidad de sus propuestas a las necesidades y a las costumbres de un determinado grupo o la incidencia que la nueva estética tiene en esa comunidad.

Es mediante el conocimiento de los epígonos no monumentales, de las ramificaciones populares, de los conjuntos de edificios popularizados, cómo un estilo artístico, uno de los grandes valores testimoniales de un cultura específica, se expande en sus límites. Pero además, es a través de estas expresiones populares como se descubre la muerte, en un sentido literal, de un estilo o su pervivencia a lo largo de los siglos convertido en invariante. Un estilo arquitectónico desaparece o se mantiene diluido en las formas popularizadas del mismo ${ }^{18}$.

En este punto nos encontramos con un nuevo problema: el de la cronología, ya que los límites temporales habitualmente aceptados para cualquier estilo artístico se han determinado atendiendo, exclusivamente, a sus manifestaciones cultas y han relegado y marginado ese conjunto de construcciones popularizadas; por lo tanto, no se ha incluido en esa datación la fase final del estilo.

Situar algunas de las construcciones populares dentro de un simplista esquema secuencial de la evolución del arte y de los estilos artísticos ha llevado a desaciertos como crear nuevas categorías y subdivisiones estilísticas para explicar esta situación. El denominado estilo protogótico es un ejemplo notable de este equivoco. Su existencia se asentó y se teorizó sobre la presencia de elementos innovadores en un conjunto de pequeñas iglesias populares ubicadas en mínimos núcleos perdidos, entre otras, en las sierras de las provincias de Guadalajara y Cuenca, es decir, explicó estos edificios como construcciones novedosas, elementos de transición o anticipación del gótico y, en última instancia, tentativas precursoras de obras tan complejas y magníficas como nuestras mejores catedrales clásicas, simplemente por dos hechos, uno situarse dentro de los límites cronológicos del gótico y dos, tener un arco apuntado en su escueta portada. Explicación que, desde luego, pierde de vista la relación entre lo particular y lo general-estructural, olvida la conexión directa entre la obra y el grupo social que la produjo y, en fin, confunde las hipótesis que se formulan para tratar teóricamente estas edificaciones con una inaceptable división de la historia en etapas y de la arquitectura en estilos, de los que unos serían consecuencia o anticipación de los otros sin más ${ }^{19}$.

18 lbidem, págs. 405-415. Argumentamos la teoría del mantenimiento de la estructura románica como invariante a lo largo de los siglos.

$19 \mathrm{Ibidem}$, págs. 48-51. Explicamos las razones por las que la aplicación de la categoría de protogóticas a este conjunto de iglesias era insostenible. La categoría del protogótico fue expuesta en AzCÁRATE, José María: El arte Gótico en España, Madrid, Cátedra, 1990. 
Para completar esta necesariamente generalista exposición de ideas, voy a realizar un análisis algo más concreto de las expresiones populares de varios de los estilos artísticos más reconocidos. Con él me gustaría incidir en el concepto, por supuesto, de popularización de la arquitectura, pero también en que éste es un hecho permanente a lo largo de toda la historia de la misma hasta el siglo xx.

Tal vez, es el estilo románico la muestra más generalizada y comprensible de la adaptación de soluciones arquitectónicas cultas contrastadas a las limitaciones locales, soluciones que se convierten en el sustrato cultural asimilado por la arquitectura popular (imágenes 1, 2, 3, y 4). Este fenómeno, como ya he comentado, va a provocar que un lenguaje elaborado previamente, de la complejidad del de un estilo internacional tan desarrollado como el románico, inicie un proceso continuo de popularización, que va a ser el resultado de una esquematización del sistema que desvirtúa los rasgos estilísticos, hace que se pierda monumentalidad y que se reduzcan progresivamente tanto los valores simbólicos como los significados (imágenes 7 y 8) y, desde luego, los sistemas constructivos; esto da lugar a una inmensa producción de edificios con un modelo cristalizado e inmutable convertido ya en invariante arquitectónico (imágenes $9,10,11$ y 12).

En concreto, es este sustrato cultural románico, asumido por la cultura popular, el que acompañó a los repobladores cristianos de la cuenca del Tajo una vez afianzada la reconquista militar, y propició la construcción de iglesias románicas en todos y cada uno de los nuevos asentamientos de colonización. La fusión entre lo religioso, lo social y lo arquitectónico, unido a las limitaciones económicas, van a definir el resultado del "último románico», que se caracteriza, a efectos de reconocimiento artístico, por la humildad y la discreción de sus realizaciones.

Este románico popularizado se convierte en el lenguaje idóneo de la sociedad que surge de la Edad Media, que se establece con un carácter profundamente religioso y espiritual, cristiana en sus sentimientos e hierática en su organización. La lenta evolución que sufre durante siglos la mantiene dentro de las mismas formas de propiedad y de la organización del trabajo, así como de las mismas fuentes de educación, de los métodos de enseñanza y de la transmisión de conocimientos. Por ello nos parece sorprendente que la concepción de su arte pudiera cambiar de repente. Como suele ocurrir con las formas e instituciones establecidas firmemente, el románico de repoblación ahora convertido en raíces culturales, se mantuvo intacto por más tiempo que el espíritu que lo había originado.

Esta popularización fue posible, además, por el propio sistema constructivo del estilo que, debido a su simplicidad, una vez despojado por las naturales limitaciones económicas de su monumentalidad y de aportes decorativos, se convierte en una arquitectura elemental, integrada en sus formas y conceptos con el resto de las arquitecturas domésticas habituales (imágenes 13, 14, 15 y 16). Como ellas, 


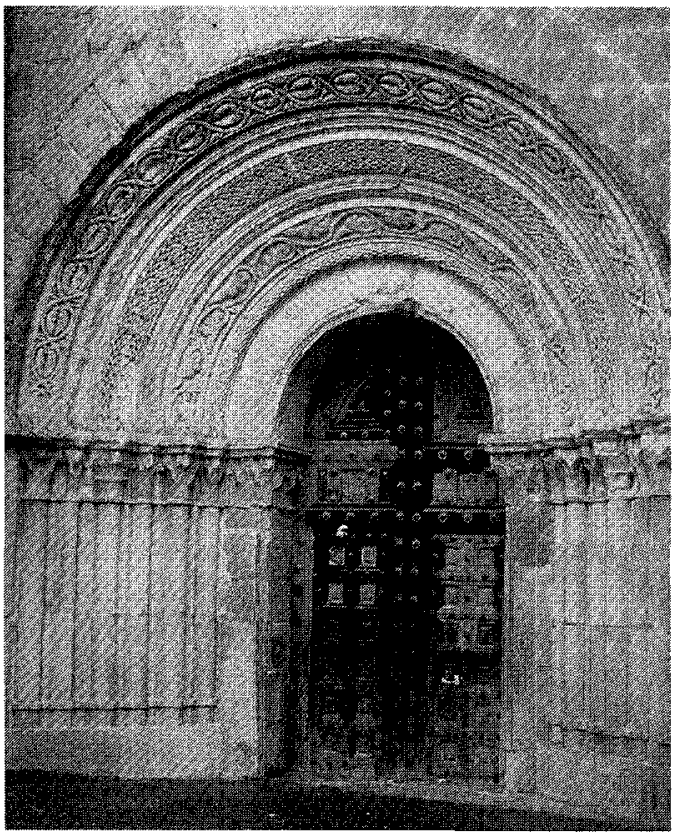

Fig. 9. Portada de la iglesia románica de Sigüenza (Guadalajara).

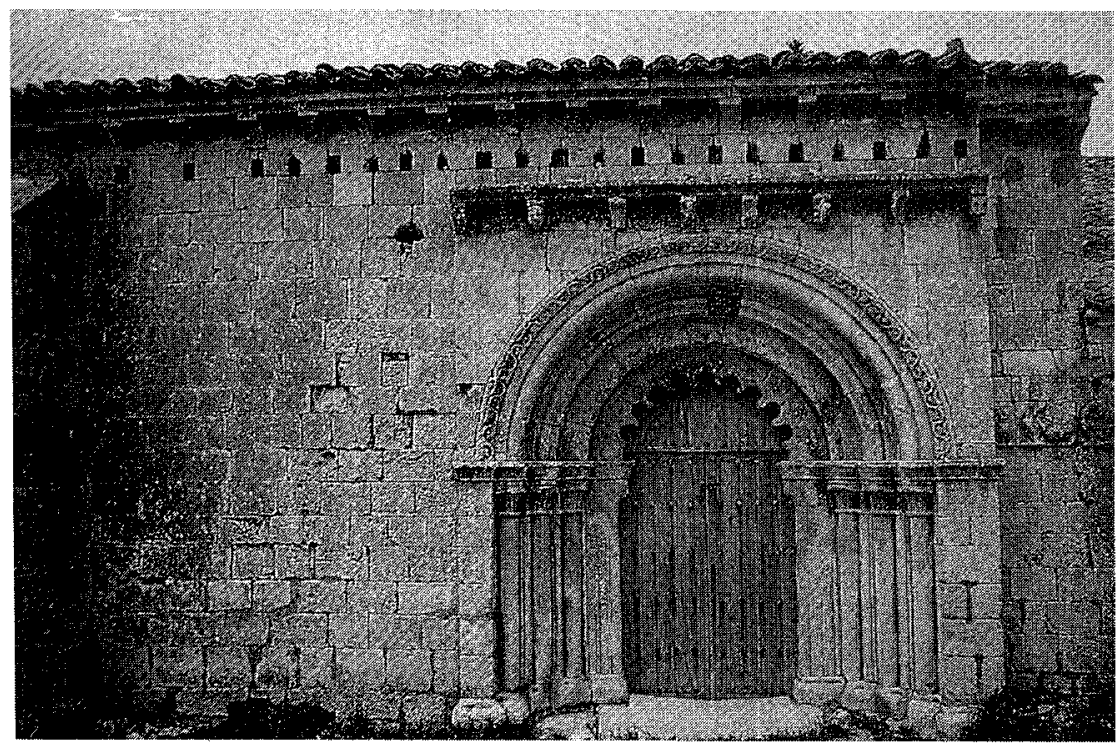

Fig. 10. Portada de la iglesia románica de Campisabalos (Guadalajara). 


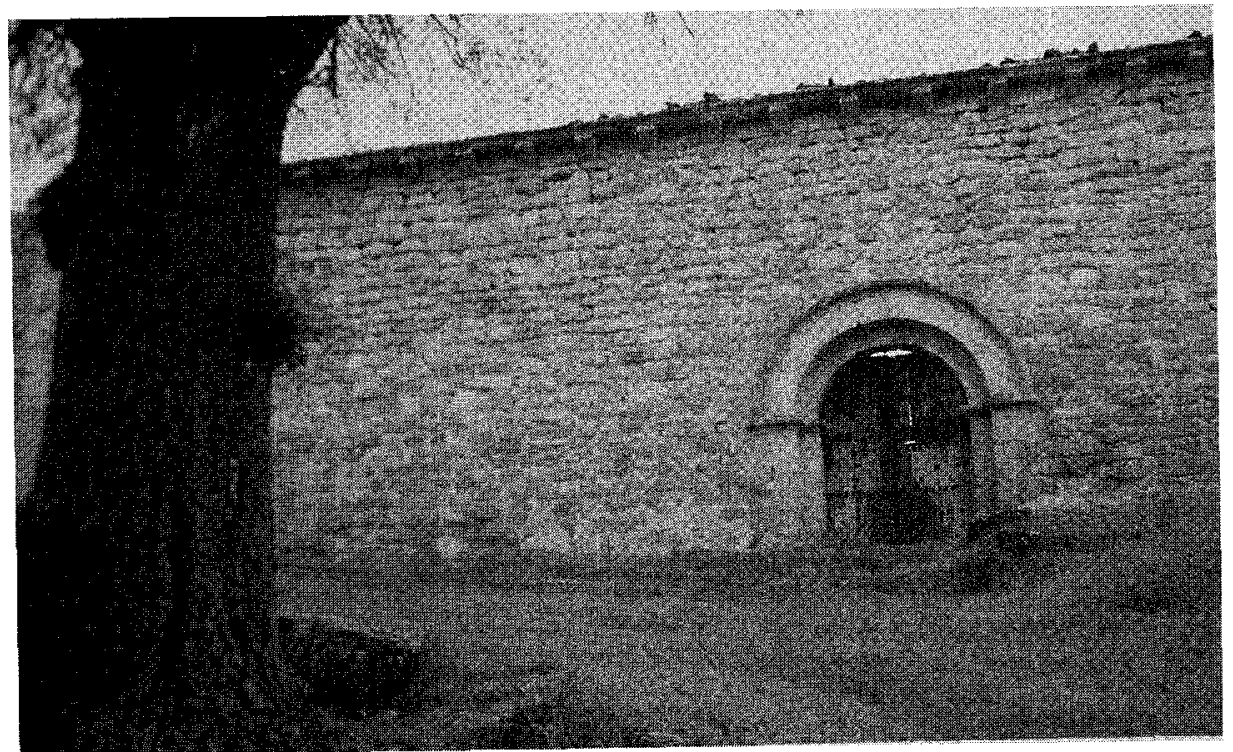

Fig. 11. Portada de la iglesia románica de Abia de la Obispalia (Cuenca).

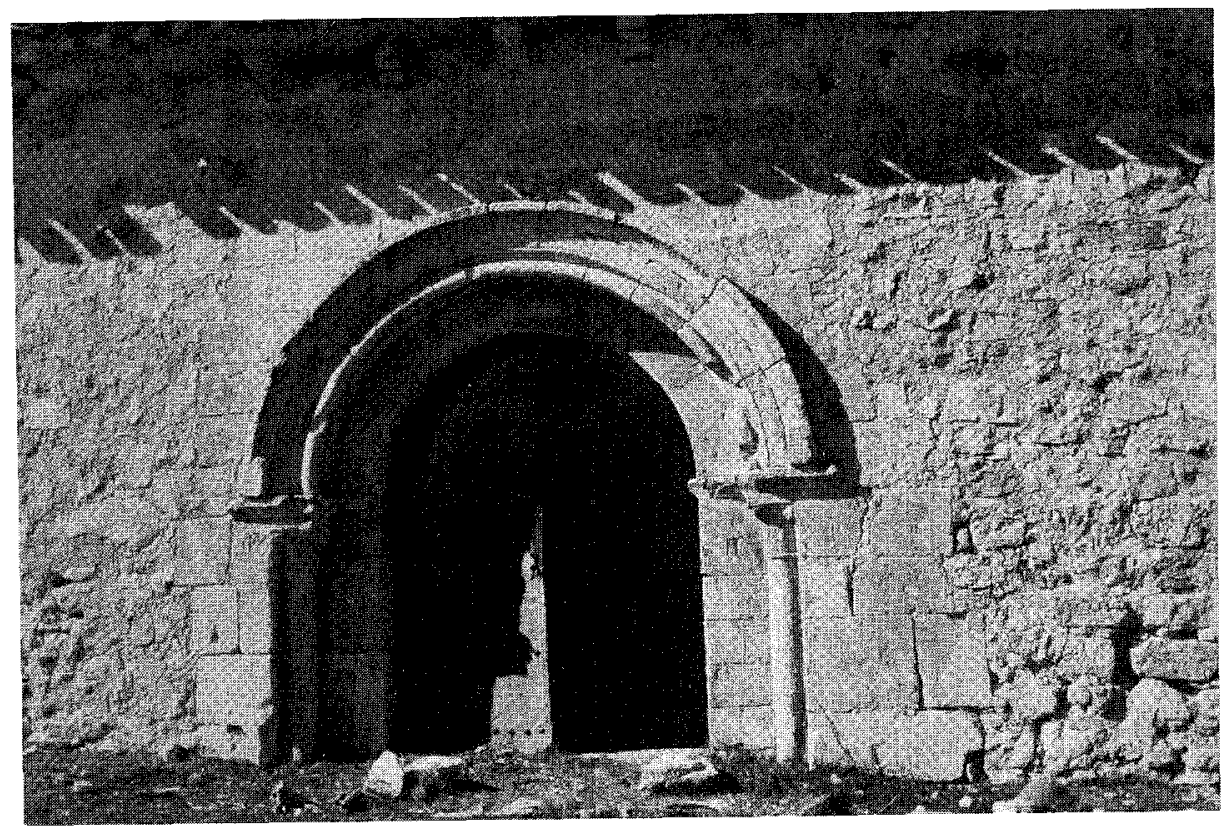

Fig. 12. Portada de la iglesia románica de Villar del Gato (Guadalajara). 
basa su ejecución en el trabajo a compresión de sus masivos elementos principales: muros de carga que soportan sencillas armaduras de madera o arcos y bóvedas de elemental factura; arquitectura de gravedad que no necesita para su ejecución medios tecnológicos singulares, ni una mano de obra especializada, trabajo de albañiles sin gran formación y sin especiales conocimientos técnicos; hechos que van a permitir que el estilo sea comprendido y asimilado por colonizadores humildes que lo van a generalizar y universalizar popularizándolo.

Este estilo, ya estandarizado y asumido por esa sociedad repobladora, permanece durante siglos, existen arquitecturas románicas al menos hasta el siglo XVI, ahora convertido en un invariante popularizado y reducido a un total esquematismo, que se extiende en un mundo que se seculariza progresivamente, y que da lugar a unas edificaciones que presentan una estructura, teóricamente, idéntica a las del románico inicial pero que se manifiestan, con toda naturalidad, con un lenguaje y una imagen: materiales, colores, texturas, proporciones y volúmenes de construcciones netamente populares.

La arquitectura gótico se proyecta con un carácter fundamentalmente urbano, no destinada a reducidos grupos de población con recursos, técnicas y necesidades limitadas. Lo que la caracteriza es su complejidad constructiva, estructural y simbólica, que la hace inaccesible para la cultura popular.

El estilo gótico desarrolla un espacio diferenciado de la realidad, unificado, vacío interior de carácter visionario, transformado en irreal y simbólico mediante la luz transfigurada y coloreada que filtran las vidrieras. Un espacio definido por muros desdoblados, paredes traslúcidas y una ordenación interior acentuada por la disposición de los apoyos exentos. El sistema de iluminación crea un ámbito sagrado simbólico, desvinculado, por falta de referencias, con cualquier escenario natural ${ }^{20}$.

Y si el espacio se convierte en una realidad inmaterial y trascendente, el continente se caracteriza por la ficción estructural, que se basa en el traslado de las cargas y de los esfuerzos al exterior del edificio donde se recogen y neutralizan, y la desaparición de los elementos portantes en el interior. Esta solución es técnicamente muy compleja, y tiene como objeto la desmaterialización del conjunto construido a través de esa artificiosa realidad estructural.

No es extraño que un estilo así defirido y así ejecutado no estuviese, bajo ningún concepto, al alcance de un conjunto social técnicamente poco desarrollado, no arraigase como nuevo estilo popular, no fuera entendido, no pudiese ser reinterpretado, simplificado, esquematizado, ni adecuado a las necesidades y asumido

${ }^{20}$ Nieto AlCAIDE, Víctor: La luz, símbolo y sistema visual, Madrid, Cátedra, 1978. 


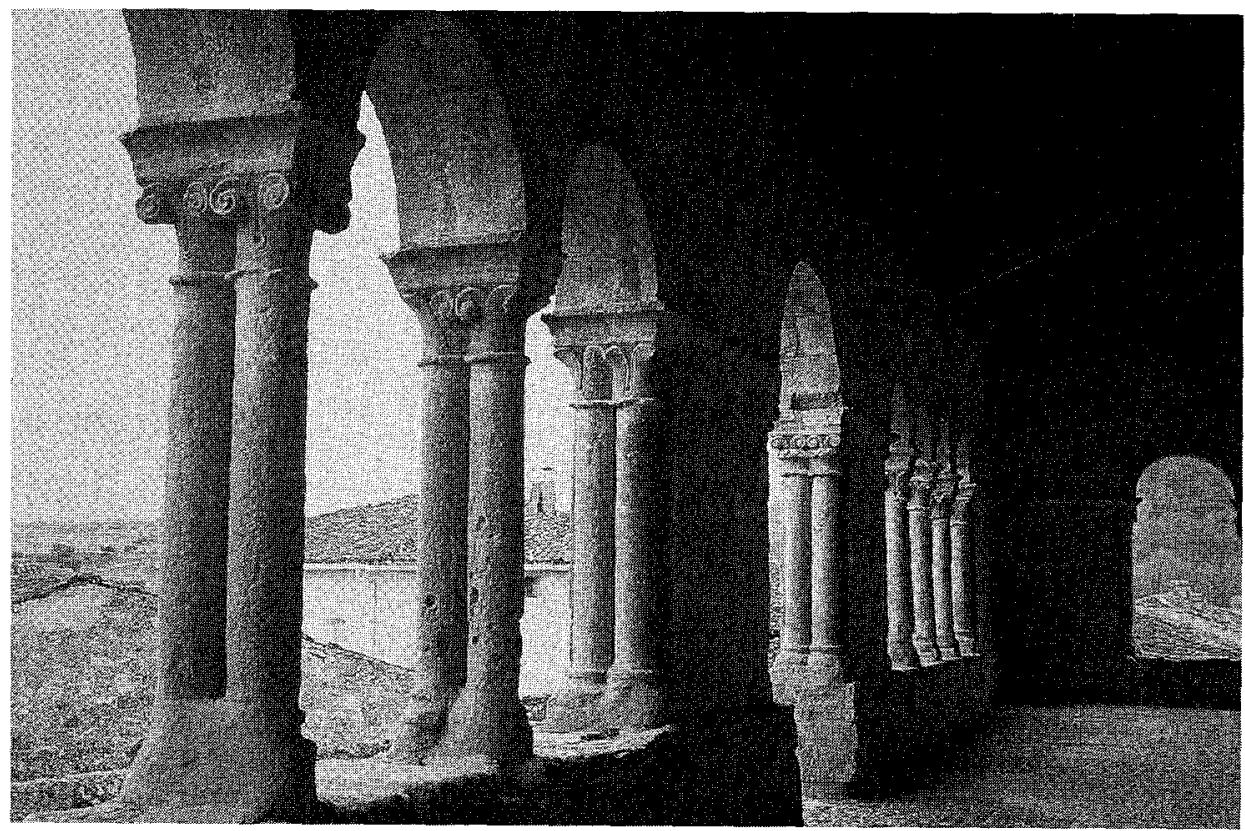

Fig. 13. Galería porticada de la iglesia románica de Pinilla de Jadraque (Guadalajara).

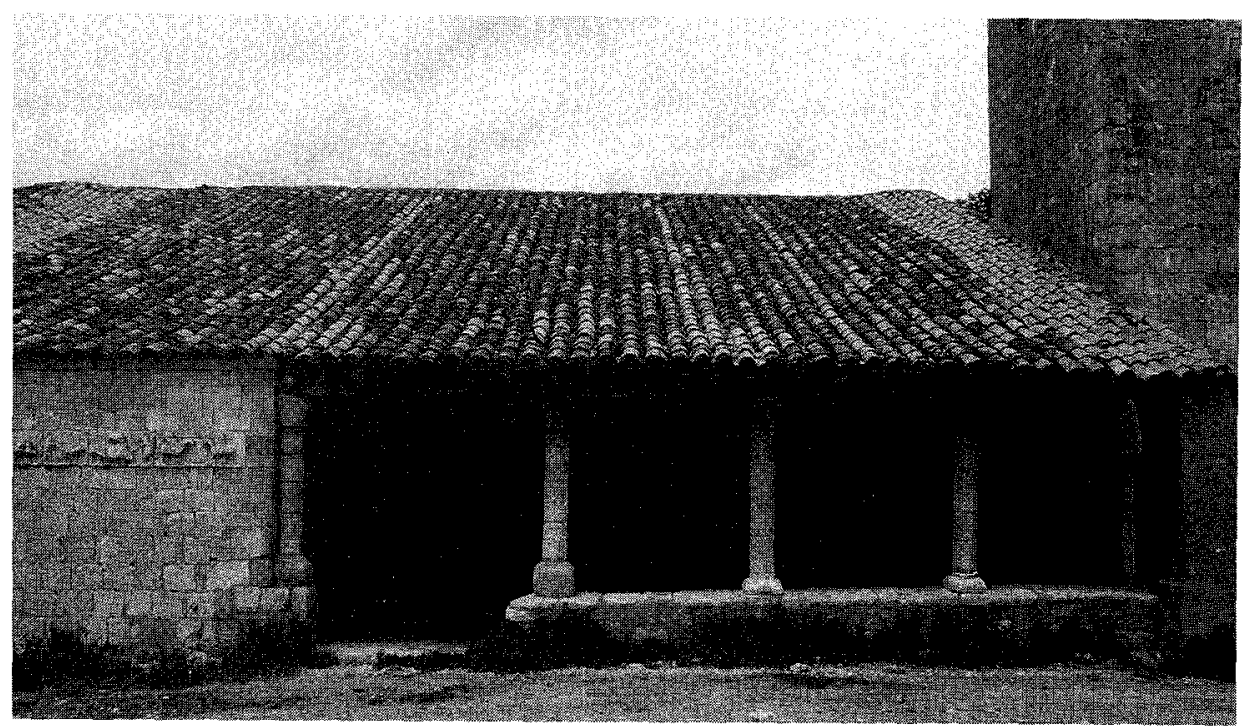

Fig. 14. Pórtico de la iglesia románica de Campisabalos (Guadalajara). 


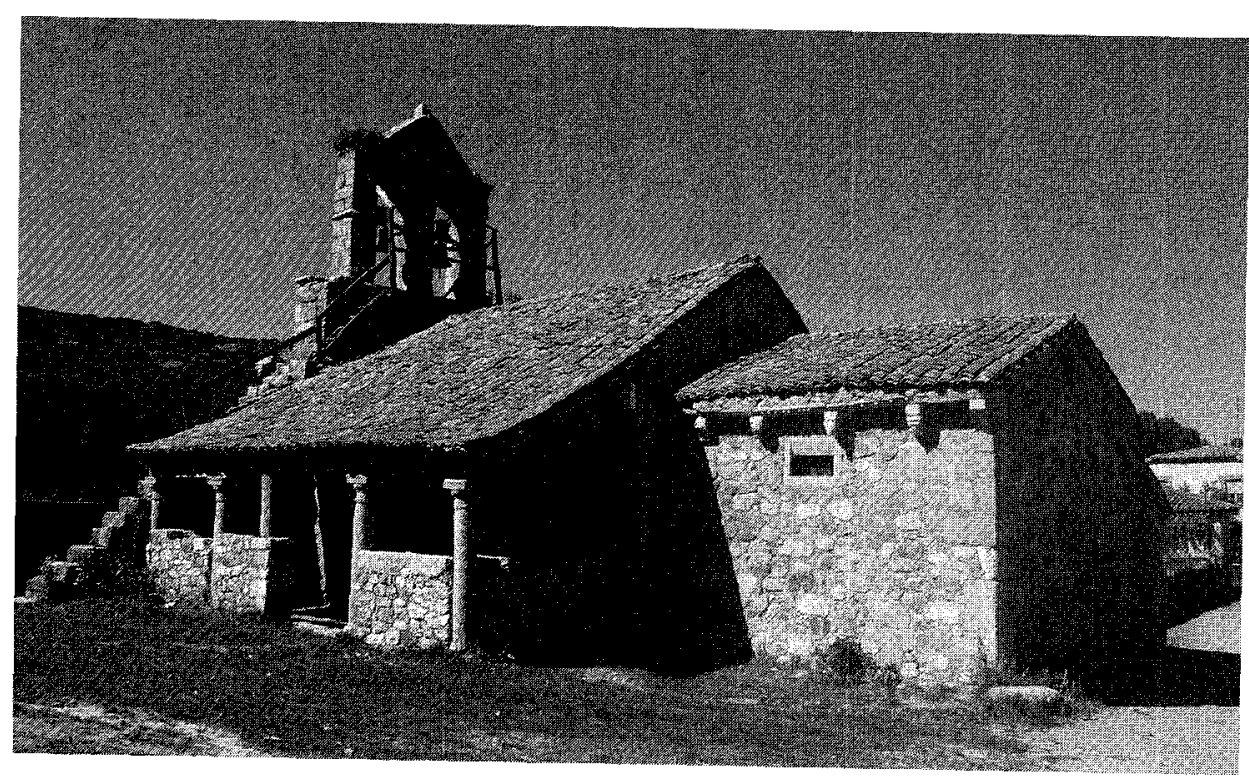

Fig. 15. Pórtico de una iglesia de Soria (Soria).

como propio por la cultura constructiva popular. Por lo tanto la arquitectura que se realiza en los núcleos menores desde el siglo XIII al XVI sigue siendo la románica.

Tienen que pasar estos tres siglos, para poder observar un nuevo proceso de popularización de este estilo gótico. Su mantenimiento hasta bien entrado el siglo $\mathrm{XVI}$, permitió que en las últimas fases se produjera una reducción de esa complejidad que hemos mencionado, tanto de sus métodos y soluciones constructivas, como de su carga espacial simbólica. Durante el reinado de los Reyes Católicos se desarrolla una gran actividad constructiva que lleva al estilo hasta los últimos rincones del reino. Pero ya es un gótico disminuido, donde el muro ciego ha sustituido en gran parte a los vanos que crearon ese espacio figurado y simbólico, ahora definitivamente empobrecido. La vuelta a los masivos muros opacos portantes permite la disposición de cubiertas y bóvedas cuyos empujes son absorbidos por estos muros ayudados por elementales y macizos contrafuertes, con lo que desaparecen los antiguos artificios de estructuras espaciales exteriores que hicie-
ron posible los muros traslúcidos.

Esta vuelta a soluciones estándar, sin complejidades simbólicas y sin especiales dificultades técnicas, permite a los artífices populares asumir estas formas como propias e incluirlas en su producción habitual como expresión natural de la sociedad civil, hecho que posibilita una nueva popularización de un gran estilo ar- 


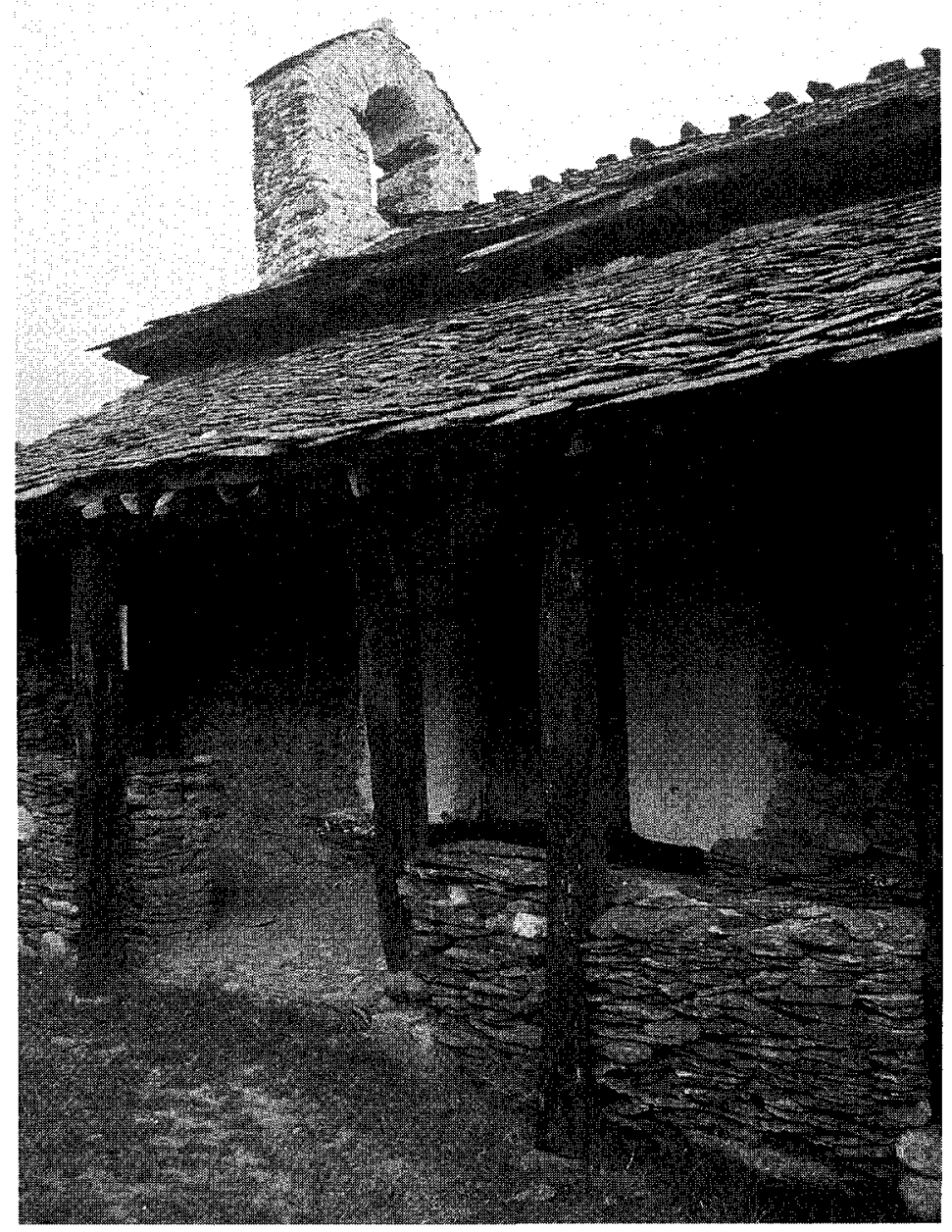

Fig. 16. Pórtico de la iglesia de La Vereda (Guadalajara).

quitectónico. Aunque, debemos precisar, que este fenómeno no arraigó con la fuerza y la universalidad con que lo hizo el románico.

Sin embargo, la euforia edificatoria de la época va a facilitar la formación de albañiles y canteros en las grandes obras urbanas y su posterior traslado a núcleos menores, donde realizan intervenciones continuas, a to largo de todo el siglo XVI, que se concentran, fundamentalmente, en el gran conjunto de las iglesias populares románicas. La renovación en el nuevo lenguaje aprendido, simplificado y asumido, se va a fijar en la sustitución de sus ábsides semicirculares por inmensas 
cabeceras de planta poligonal, cubiertas de sencillas nervaduras y muros portantes masivos y opacos ${ }^{21}$ (imágenes 17 y 18).

Es la segunda aportación generalizada de un estilo internacional al conjunto de las arquitecturas asimiladas e interpretadas como populares.

La Edad Moderna es una época fundamental para la popularización y la integración de construcciones. Cambios como el florecimiento de la vida urbana, la aparición de nuevas clases profesionales y de corporaciones organizadas de oficios, el desmantelamiento lento y progresivo de la estructuras sociales antiguas y la secularización de la cultura, inician el camino, ya imparable, de la intervención de nuevos grupos sociales, una incipiente burguesía, en el arte y la arquitectura, disminuyendo proporcionalmente la influencia artística del clero.

Esta nueva sociedad civil tendrá un papel cada vez mayor en la definición de las construcciones y corporativamente, como municipio, una influencia importante en la composición de los inmuebles religiosos y en el diseño de obras municipales.

Toda esta época se va a caracterizar por la continua y generalizada trasposición a soluciones populares, en los edificios donde las condiciones económicas lo imponen, de ejemplares de arquitecturas cultas. La repetición de estos modelos se universaliza en todas las tipologías, hasta el punto que se puede afirmar que no existe una arquitectura culta que no se haya reinterpretado en lenguaje popular convirtiéndose en un invariante.

Las fórmulas constructivas renacentistas y barrocas, en un siempre repetido proceso de esquematización y simplificación, estaban al alcance de los conocimientos y de las técnicas habituales de los alarifes menores, que ejecutaron sus versiones con toda naturalidad y, esta vez, coincidiendo en el tiempo y el lugar con las obras de estilo.

Es en la Edad Moderna cuando estos préstamos y estas interacciones se generalizan, los edificios singulares van a ser la inspiración y van a marcar las pautas para el resto de las construcciones en un proceso de unificación arquitectónica sin precedentes.

Si en épocas anteriores los esfuerzos de popularización se centraron en los inmuebles religiosos como tipologías únicas, en la Edad Moderna la nueva composición social diversificada y la prospera situación económica real, hicieron viables intervenciones populares, no sólo en el corpus de las iglesias medievales, donde

${ }^{21}$ Este fenómeno se puede estudiar en Nieto Taberné, Tomás y Alegre Carvajal, Esther: El Románico en Guadalajara...; Nieto TABerné, Tomás y Alegre CARVAJAL, Esther: El Románico en Cuenca...; donde al igual que el estilo románico, se analizan todas las transformaciones sufridas por estos edificios. 


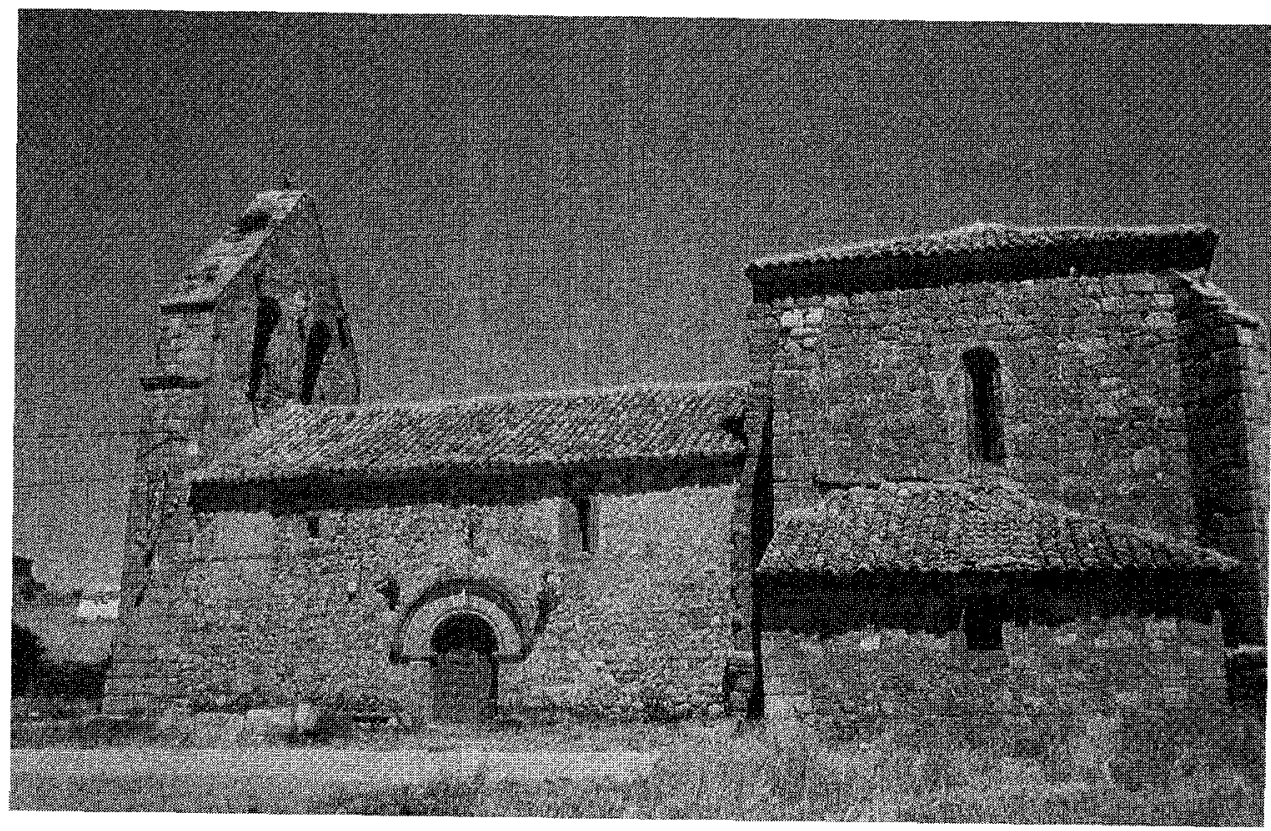

Fig. 17. Iglesia románica de Bocones (Guadalajara) con cabecera gótica.

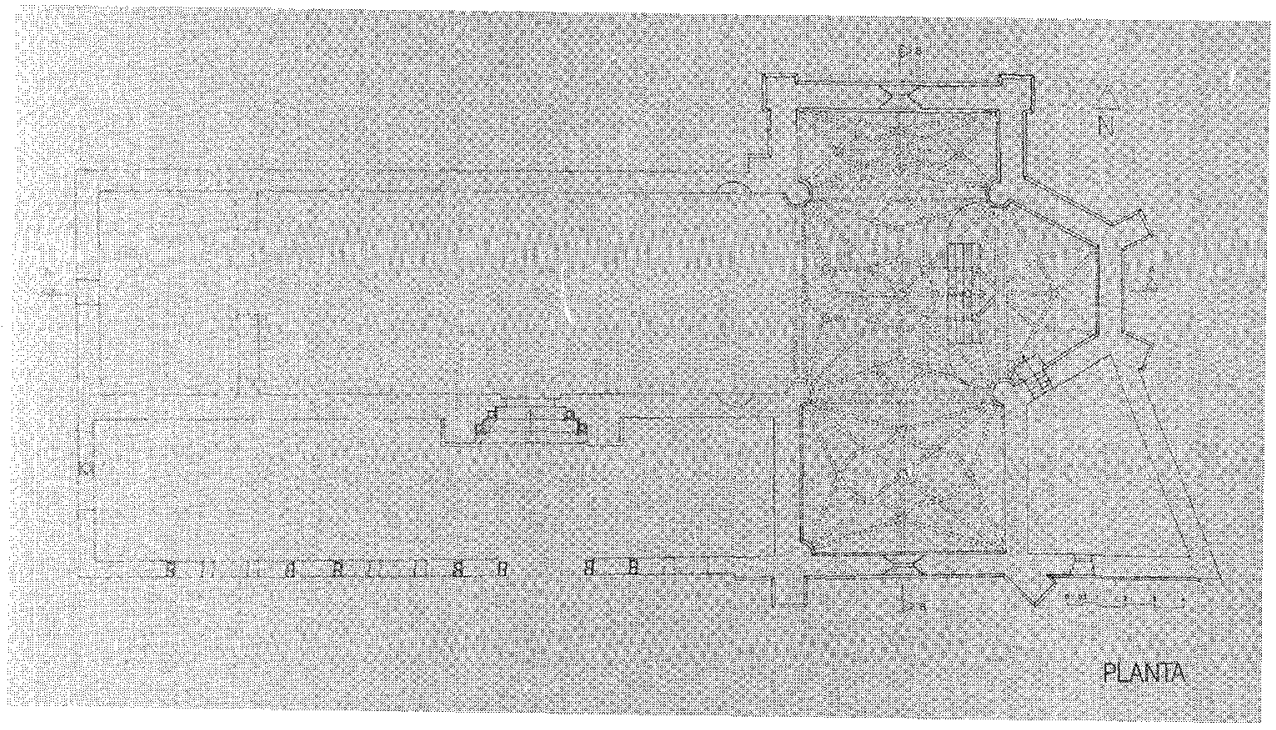

Fig. 18. Planta de la iglesia románica de Beleña (Guadalajara) con cabecera gótica. 


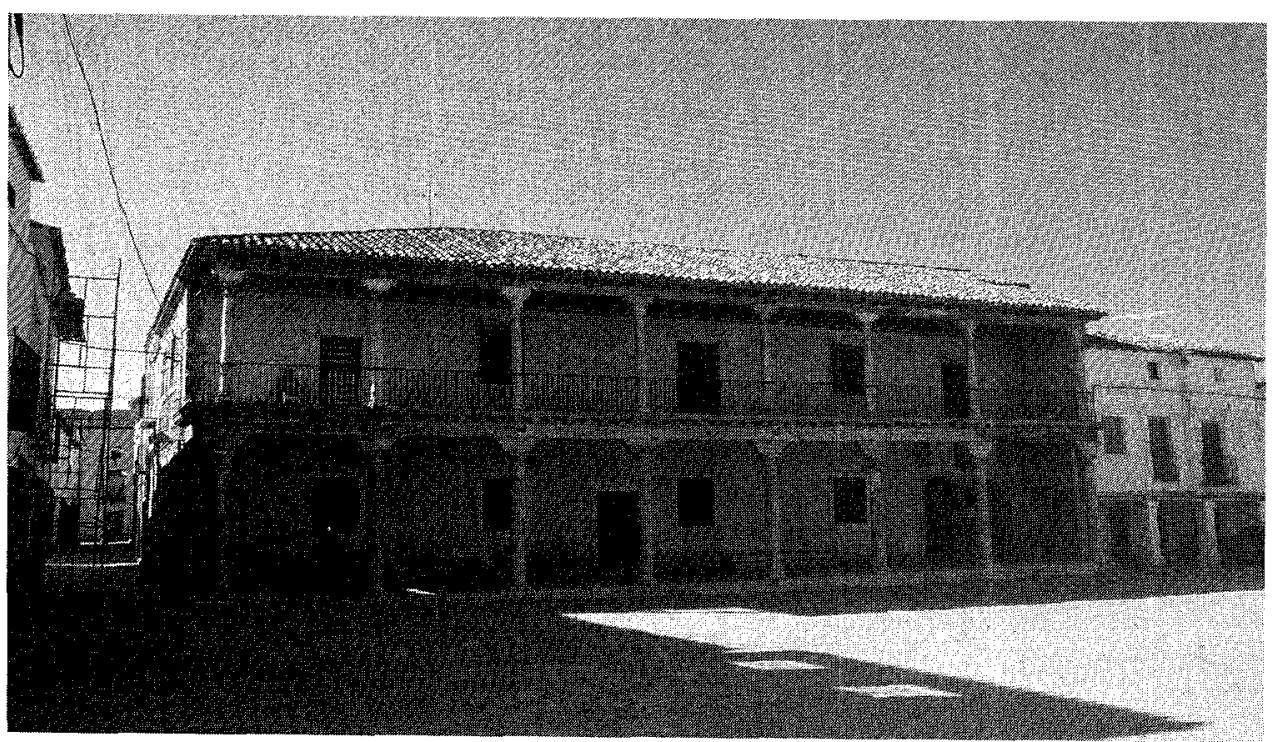

Fig. 19. Ayuntamiento renacentista de Fuentelencina (Guadalajara).

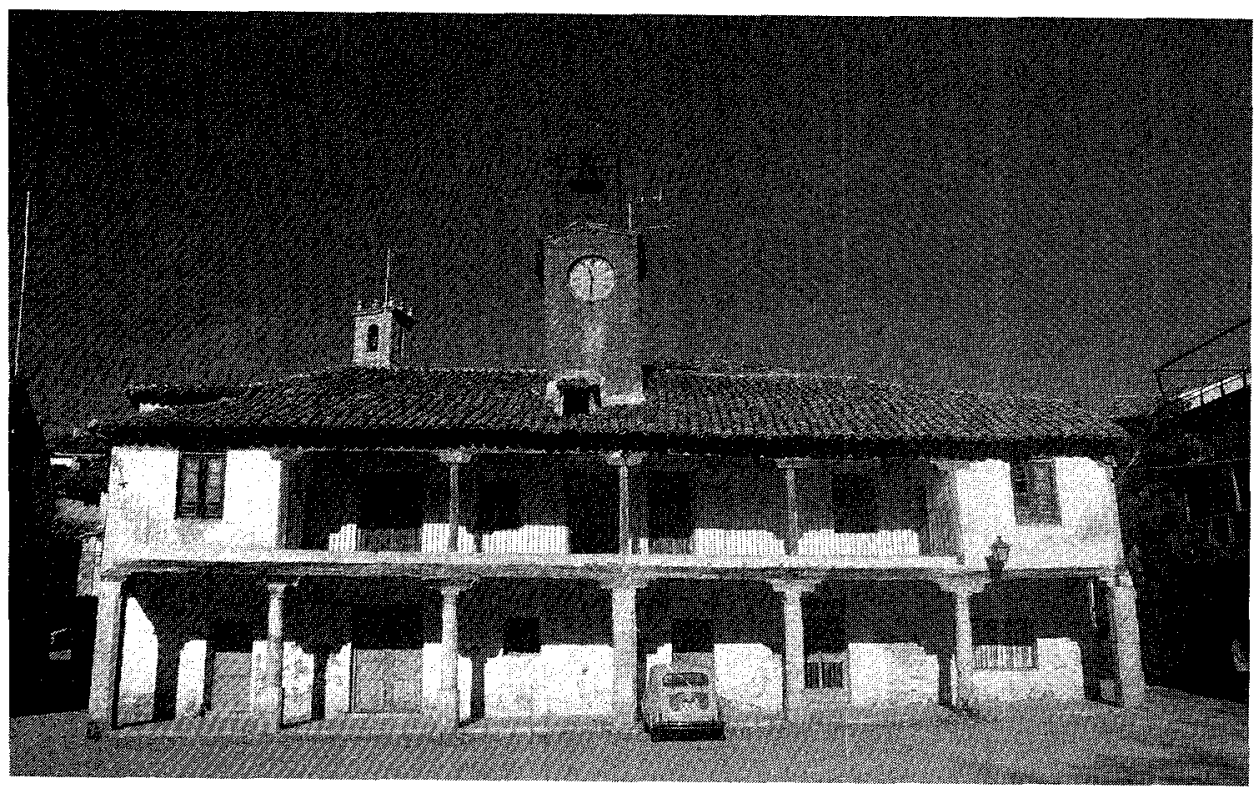

Fig. 20. Ayuntamiento renacentista de Lupiana (Guadalajara). 


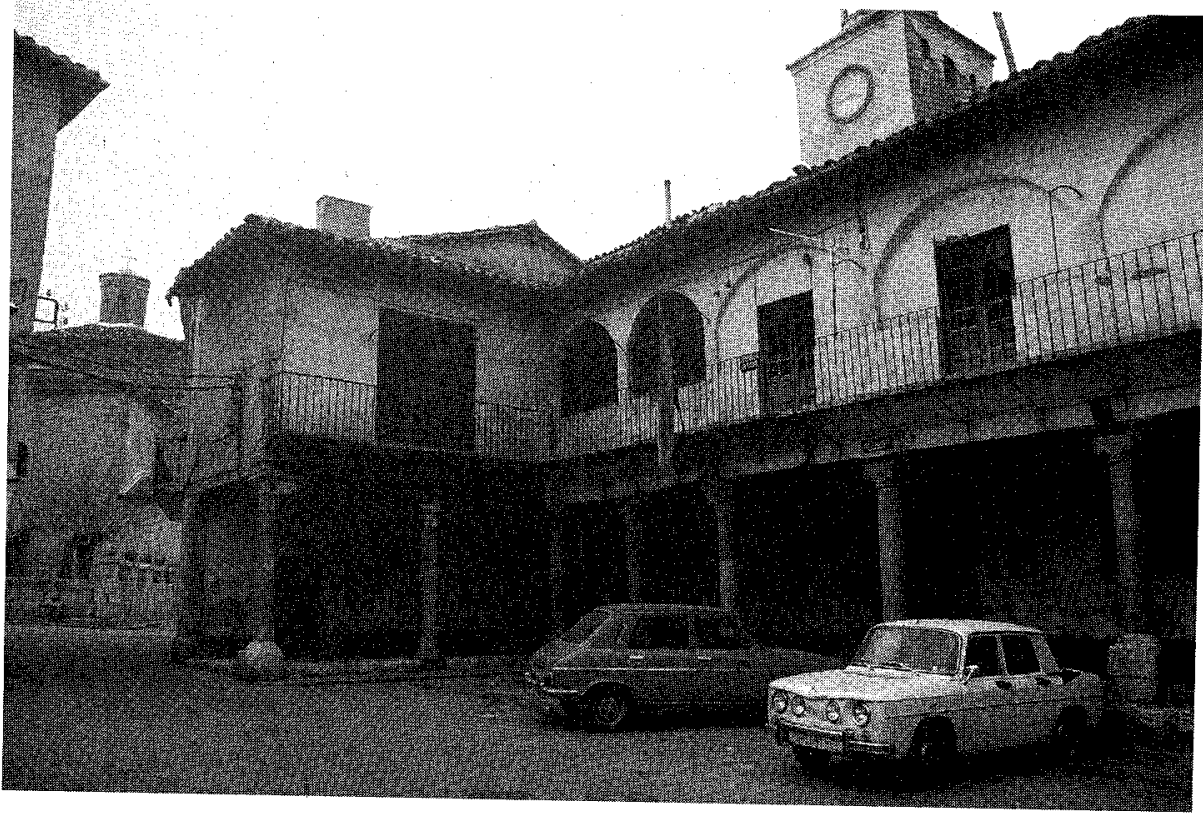

Fig. 21. Ayuntamiento de Budia (Guadalajara).

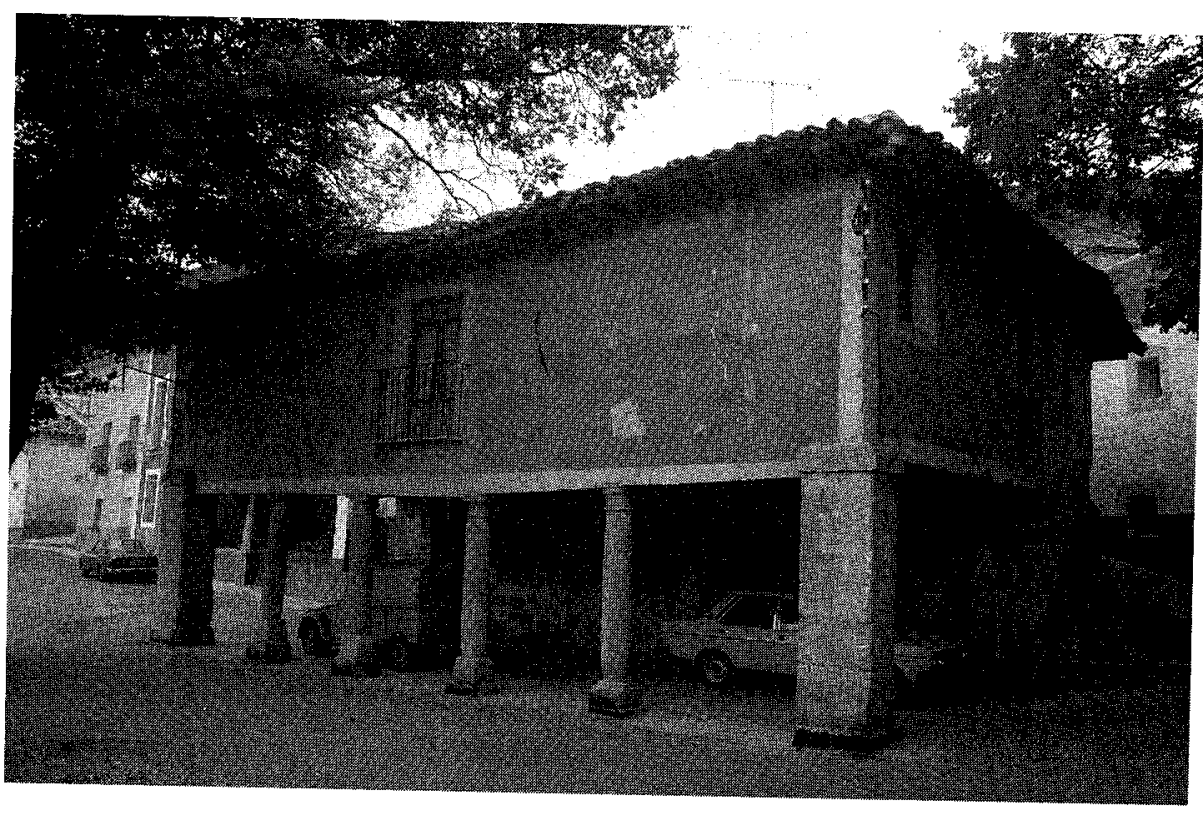

Fig. 22. Ayuntamiento de Durón (Guadalajara). 
reiteradamente se sustituyen las cabeceras o se adosan capillas con simples y rotundos volúmenes cúbicos; sino que toda la arquitectura doméstica de cierta calidad va a ser consecuencia de intentos de interpretación emuladores de las arquitecturas cultas.

La aparición de originales modelos de edificios va a marcar los siglos siguientes. Común va a ser en estos momentos, dado el pujante desarrollo de la organización municipal, la construcción de Ayuntamientos, fábricas renacentistas que siguen una estructura de fachada dividida en dos pisos con doble galería formadas por arquerías o estructuras adinteladas superpuestas construidas en diferentes órdenes clásicos, que en su expresión popular se transforman en vigas de madera apoyadas en elementales zapatas sobre columnas de madera. Esta tipología arquitectónica se utiliza por toda la península y se mantiene como invariante hasta el siglo xx (imágenes 19, 20, 21 y 22).

La reinterpretación va a implicar a otros modelos que se resuelven con el mismo sistema arquitectónico y que tienen idénticas expresiones tanto en las construcciones de estilo como en las populares. Entre ellos, y como ejemplo paradigmático, los palacios con patio central, resueltos con galerías clásicas en los mejores ejemplos renacentistas, y en su versión popular con vigas, zapatas y pies derechos de madera, con una amplísima difusión en todas las regiones.

Estas galerías, abiertas en la fachada o limitando los patios interiores de los edificios palaciegos, van a ser igualmente utilizadas por el diseño urbano, que las incorpora e interpreta en el ingente número de calles, plazas y recintos porticados, realizaciones cultas y populares indistintamente, que encontramos a lo largo de todos los pueblos y ciudades de España.

La unificación, tanto urbanística como arquitectónica, se hace posible por el uso asociado de sistemas constructivos "a la antigua" comunes a las diferentes edificaciones. Esta fusión se efectúa a lo largo de toda la Edad Moderna y hasta la aparición de los métodos industriales de construcción, simplificando el aprendizaje de oficios que van a compartir las soluciones cultas y las populares; el muro de carga, los forjados planos con viguería de madera, los huecos adintelados, las galerías y los patios porticados, el dominio de la luz natural, van a conformar todas las tipologías arquitectónicas cultas, que uniformemente, más o menos popularizadas, van a plasmarse tanto en el espacio urbano como en las construcciones populares.

Tras este intenso proceso de alianza arquitectónica, la ruralización que se produce en el conjunto de los núcleos urbanos medianos en el siglo XIX va a significar un último proceso de popularización en el patrimonio construido, con la reutilización de los edificios y la transformación de su apariencia. No se va a popularizar la arquitectura preexistente sino que sobre ella se van a realizar adiciones, 


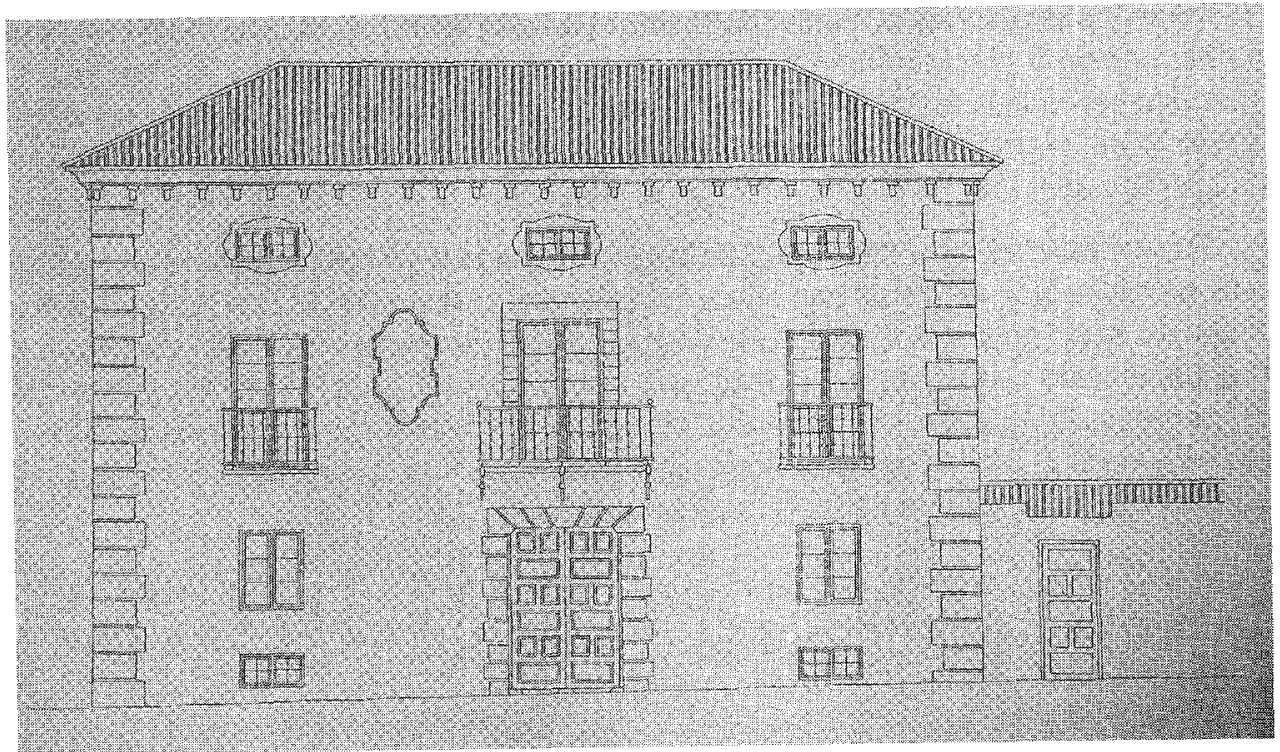

Fig. 23. Palacio barroco de los Burgo en el siglo XVII. Pastrana (Guadalajara).

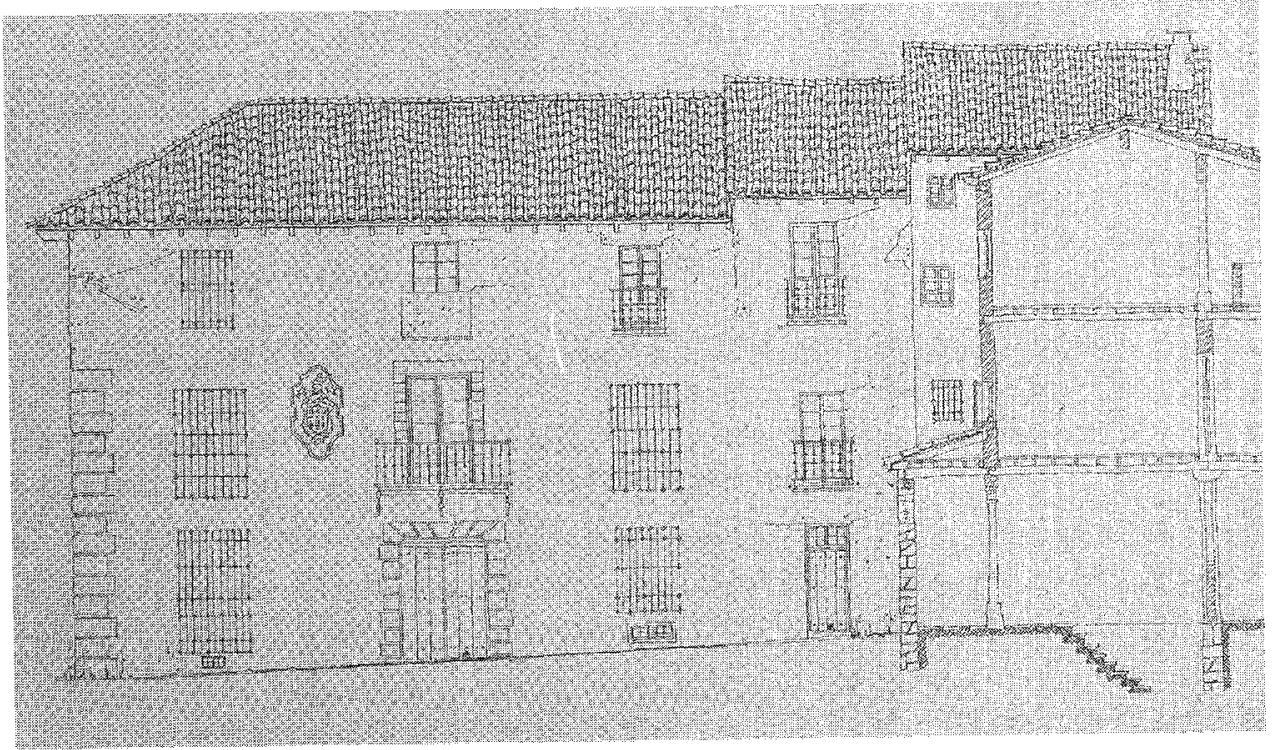

Fig. 24. Palacio barroco de los Burgo en los siglos xix y Xx. Pastrana (Guadalajara). 
reformas y alteraciones utilitarias de factura popular, cambios de uso, de intensidad de ocupación y funcionales que van a introducir, como consecuencia, inéditas fisonomías en primitivos edificios, ahora maclados con las construcciones populares colindantes, ejemplos de la integración de arquitecturas en composiciones únicas (imágenes 23 y 24 ).

Esta ruralización se produce por la generalizada escasez de recursos, hecho que propicia que las reutilizaciones mencionadas alcancen a casi todos los inmuebles que, en pasadas épocas de prosperidad, se construyeron con estilos arquitectónicos cultos. Su popularización, ahora generalizada, comporta el cambio de percepción no ya sólo de la arquitectura, sino también de los espacios ciudadanos y de los núcleos como un todo, que adquieren la apariencia de conjuntos urbanos populares que ha llegado hasta nosotros. 